\title{
Mechanism of Action and Efficacy of Immunosupressors in Lupus Nephritis
}

Mario E Alamilla-

\author{
Sanchez (1D)
}

Miguel A Alcala-Salgado'

Cesar D Alonso-Bello²

Gandhy T Fonseca-

Gonzalez'

'Department of Nephrology, Centro Medico Nacional "20 de Noviembre", Mexico City, Mexico; ${ }^{2}$ Department of Immunology, Centro Medico Nacional

"20 de Noviembre", Mexico City, Mexico

Correspondence: Mario E AlamillaSanchez

Department of Nephrology, Centro

Medico Nacional "20 de Noviembre",

Mexico City, Mexico

Tel +525541334931

Email silenozl@hotmail.com
Abstract: Approximately $70 \%$ of the patients with systemic lupus erythematosus will have clinical evidence of kidney damage during their evolution. Patients with impaired renal function at onset and those with recurrent flares have a poor prognosis. Understanding the mechanism of action of immunosuppressants is essential for proper prescription. Steroids inhibit the DNA sequence that promotes the release of inflammatory cytokines. Phosphoramide mustard, metabolite of cyclophosphamide, cross-link with the DNA, causing the aggregation of an alkyl group, causing cell death. Mycophenolate inhibits inosine monophosphate dehydrogenase, prevents de novo synthesis of guanine, inducing cell arrest in S phase. Azathioprine blocks the synthesis of purines and induces apoptosis. Calcineurin inhibitors prevent the dephosphorylation of NFAT and reduce the production of interleukin 2. Antimalarials alter the enzymatic release of lysosomes by increasing intravesicular $\mathrm{pH}$. The mechanism of action of rituximab is related to complement-dependent cytotoxicity and the elimination of anti-CD20-labeled B cells. Progress in the knowledge and management of low doses of steroids may change the current paradigm and reduce the frequency of related adverse events. Mycophenolate seems to be a better choice than cyclophosphamide for induction, it is also preferred over azathioprine as a maintenance immunosuppressive agent, although azathioprine is preferred in women with a desire for conception, those pregnant, or with low resources. For treatment-resistant cases, tacrolimus, rituximab or belimumab may be effective. Ongoing clinical trials with new drugs offer promising results. Keywords: systemic lupus erythematosus, lupus nephritis, mechanism of action, therapeutics, clinical pharmacology

\section{Introduction}

Lupus nephritis (LN) is a common complication of systemic lupus erythematosus (SLE). Approximately $70 \%$ of the patients with SLE will have clinical evidence of kidney damage during their evolution. ${ }^{1}$ In autopsies, lupus nephritis is found in more than $95 \%$ of the patients with SLE. ${ }^{2}$ However, deposits of immune complexes have been demonstrated in the kidneys of virtually all SLE patients even if the findings by light microscopy are normal. ${ }^{3}$ Of all SLE patients, 33\% had deterioration of renal function or proteinuria at onset. $^{4}$ Patients with proliferative class (III/IV) and membranous (class V) LN have a probability of progression to end-stage renal disease of $20 \%$ and $10 \%$ at 5 years, respectively. ${ }^{5,6}$ Before 1980 it was the leading cause of death in patients with SLE, since then it is the second cause of death after infections. ${ }^{2}$ Risk factors for LN include lower age at diagnosis, male sex, being Hispanic, Asian or African. ${ }^{6}$

Patients with SLE represent $2 \%$ of hemodialysis population. Among these, women, African-Americans, and those younger than 45 years old are the largest 
group in renal replacement therapy, ${ }^{7}$ and they demonstrate a lower survival rate on dialysis than those without the disease. ${ }^{8}$ The treatment improves the patient's quality of life and reduces the number of flares.

In the following review, we aimed to briefly describe the mechanisms of action and the current usefulness of immunosuppressive therapies in proliferative $\mathrm{LN}$.

\section{Materials and Methods}

The review was carried out after searching the PubMed database for clinical trials, pharmacokinetic studies, clinical outcomes, international management guidelines, and molecular bases of the mechanism of action of the immunosuppressants used in lupus. Relevant clinical studies from 1986 to 2021 were included. Molecular-based studies from a period no longer than 10 years to date were included. Clinical studies using unapproved drugs or with little evidence for favorable outcomes in lupus nephritis were excluded.

\section{Glucocorticoids}

In 1934 researchers at the Mayo Clinic obtained an extract from the adrenal gland they called "cortin". Since then, the efficacy of the drug in the management of autoimmune diseases was proven to be successful.

Its mechanism of action is complex. It is divided into genomic and non-genomic. Genomic responses are the most important from the immunomodulation point of view and are of two types: Transactivator and transrepressor mechanisms. ${ }^{10}$

Glucocorticoids bind to the cytosolic glucocorticoid receptor (cGR), a multiprotein complex composed of heat shock proteins, immunophilins, p23 and kinases of the MAPK system. ${ }^{11}$ The binding of the multiprotein complex cGR to FKBP52 and dynein is translocated through the nuclear pore complex by an active transport mechanism mediated by alpha and beta importins. Within the nucleus, glucocorticoids interact with glucocorticoid response elements (GREs). ${ }^{10,12}$

Transactivation refers to the transcriptional activation of GREs, whereas transrepression relates to the interference of its pro-inflammatory activity. The primary transcription factors modulated by glucocorticoids include the activator protein 1 (AP-1), the nuclear factor kappa B, and interferon regulatory factor $3 .^{13,14}$

In $\mathrm{LN}$, high doses of methylprednisolone ( 0.5 to 1 $\mathrm{g}$ intravenously) before cytotoxic or antimetabolite are usually given in induction therapy, followed by oral prednisone ( 0.5 to $1 \mathrm{mg} / \mathrm{kg} / \mathrm{day})$, with dose reduction in a period of 3 to 6 months.

The use of glucocorticoids alone is associated with a $40 \%$ probability of doubling serum creatinine at 3 years compared to the combined use of steroid and cytotoxic therapy in proliferative LN. ${ }^{15,16}$

Doses greater than $7.5 \mathrm{mg}$ per day for more than 3 months are associated with a high rate of adverse events such as bone demineralization, systemic hypertension, edema, weight gain, acne, atherosclerosis, and severe infections. ${ }^{11,17}$ The duration of glucocorticoid therapy is variable, approximately $70 \%$ of the patients will continue with prednisone after induction therapy. ${ }^{18}$

Due to the high rate of adverse effects, the efficacy of steroid-free treatment has been studied. Fischer et al evaluated 40 patients with class IV LN, receiving induction therapy with CYC. Prednisone was offered only if the extrarenal activity was reported. At 2 years, complete response was achieved in $62.5 \%$ of the patients, whereas partial response was achieved in $20 \%$. Among patients who received prednisone $<20 \mathrm{mg} /$ day or $>20 \mathrm{mg}$ /day, there was no difference in renal response or flares $(\mathrm{p}=0.58) .{ }^{19}$

The MYLUPUS trial $^{20}$ compared the efficacy of reduced-dose oral steroid to standard-dose oral steroid. All patients received three $500 \mathrm{mg}$ methylprednisolone pulses plus mycophenolate acid, then randomized to either standard-dose oral steroid $(1 \mathrm{mg} / \mathrm{kg} / \mathrm{d})$ or reduced-dose steroid scheme $(0.5 \mathrm{mg} / \mathrm{kg} / \mathrm{d})$. Complete response at week 24 , the primary endpoint, was achieved in $19.8 \%$ of the patients (19.0\% standard-dose, $20.5 \%$ reduced-dose; $p=0.098)$. Infections were reported in $57.1 \%$ and $35.9 \%$ of standardand reduced-dose steroid patients, respectively $(p=0.056)$, with herpes zoster in $16.7 \%$ and $0 \%(\mathrm{p}=0.012)$.

The RITUXILUP trial evaluated 50 patients treated with $500 \mathrm{mg}$ of Rituximab (RTX) and $1 \mathrm{~g}$ of methylprednisolone at day 1 and 15, without prednisone. A combined response, either partial or complete, was achieved in $90 \%$ of the patients on an average of 37 weeks. Complete response was maintained in $52 \%$ and partial response in $34 \%$ of the patients at week $52 .^{21}$

Another study reported the efficacy of treatment with monthly IV cyclophosphamide (CYC) and fortnightly RTX, free of oral steroid, getting a significant reduction of proteinuria, stable renal function, and no evidence of extrarenal activity. ${ }^{22}$

In the AURA-LV trial ${ }^{23}$ evaluating the efficacy of voclosporin plus mycophenolate and oral steroids (see below), patients were treated with two $0.25-0.5$ 
g methylprednisolone pulses, followed by a fixed 20 $25 \mathrm{mg} / \mathrm{d}$ starting oral prednisone rapidly tapered to $5 \mathrm{mg} /$ $\mathrm{d}$ by 12 weeks, and $2.5 \mathrm{mg} / \mathrm{d}$ by week 16 . At 12 months, complete and total renal response rates comparing multitarget treatment and control group were 49 vs $24 \%$, and 67 vs $48 \%$, respectively.

Ruiz Irastorza et al evaluated the effect of low-dose (mean $9 \mathrm{mg} /$ day) compared to standard-dose (mean $25 \mathrm{mg}$ / day) of prednisone in 45 patients, obtaining a partial or complete response, at $87 \%$ vs $63 \%$, respectively $(\mathrm{p}=$ $0.05)$, but with higher rates of adverse events with the standard-dose $(67 \%$ vs $7 \%, \mathrm{p}<0.0001) .{ }^{24}$ An average prednisone dose of $7.5 \mathrm{mg} /$ day has been found to be an independent predictor of systemic damage and increased adverse events. ${ }^{25}$

Currently, different guidelines recommend a "maintenance dose" of $\leq 7.5 \mathrm{mg}$ of prednisone per day. ${ }^{26-30}$ However, the studies mentioned above may open the paradigm of chronic use of steroid in the treatment of LN. Steroid-free or low-dose therapies may have acceptable results with a reduced rate of adverse events. $^{31-34}$

\section{Cyclophosphamide}

CYC is a nitrogen mustard pro-drug that requires oxidation by the cytochrome P450 (CYP) system. Isoforms CYP3A5 and CYP2B6 produce phosphoramide mustard, which cross-link with the DNA, causing the following effects: first, the aggregation of an alkyl group to guanine on the nitrogen 7 of the imidazole ring; second, forming covalent bonds and causing the rupture of DNA doublestrand; and third, inhibition of DNA replication leading to cell death. These effects occur in both active and quiescent lymphocytes. ${ }^{35}$ The half-life of CYC is $3-12$ hours. The further metabolite, acrolein, can provoke hemorrhagic cystitis. CYC inactivation is mediated through the conjugation to 4-glutathionyl-CYC by glutathione $\mathrm{S}$ transferases (GSTs).

Oral or intravenous administration results in the same plasma concentration, which correlates poorly with efficacy or toxicity. ${ }^{36}$ The kidneys excrete $20 \%$ of the nonmetabolized drug and all metabolites. Therefore, a $25 \%$ dose reduction is suggested when the estimated glomerular filtration rate (eGFR) is between 25 and $50 \mathrm{~mL} / \mathrm{min}$ and $30-50 \%$ when the eGFR is $<25 \mathrm{~mL} / \mathrm{min}$. In hemodialysis patients, no dose reduction is required, as $22 \%$ of the drug is eliminated during a 3 -hour session. ${ }^{37}$
The cumulative dose, oral or intravenous, appears to determine the initial response to CYC treatment, although there may be increased toxicity with the enteral route. ${ }^{38,39}$

Adverse effects include infections, increased frequency of neoplasms (especially non-Hodgkin's lymphoma and cervical intraepithelial neoplasia), and gonadal toxicity. Ioannidis et al found that $31 \%$ of the patients who received CYC pulses had sustained amenorrhea. The dose at which $50 \%$ of women developed amenorrhea was $8 \mathrm{~g} / \mathrm{m}^{2}$, and the treatment at which $90 \%$ developed it was $12 \mathrm{~g} / \mathrm{m}^{2}$. ${ }^{40}$ Interestingly, women with amenorrhea have fewer severe flares than those who menstruate. ${ }^{41}$ It has been reported that patients who are homozygous or heterozygous for CYP2C19*2 have a lower risk of developing ovarian failure. $^{42,43}$

Van Casteren et al evaluated 248 men treated with CYC for cancer, $70 \%$ of those receiving $<7.5 \mathrm{~g} / \mathrm{m}^{2}$ regained fertility, whereas only $10 \%$ did so if the dose was $>7.5 \mathrm{~g} / \mathrm{m}^{2} .{ }^{44}$

Its use in LN is widely accepted. Reports from the 1970s provided evidence of its efficacy. ${ }^{45}$ However, it was not until the study by Austin et al published in 1986, became was definitive. They compared the effect of five treatment lines, including quarterly intravenous CYC administration. Renal function was better preserved in those receiving cytotoxic therapy, but the statistical significance was only better in the group receiving the intravenous $\mathrm{CYC}+$ steroid combination $(\mathrm{p}=0.027$ vs high prednisone monotherapy). ${ }^{46}$

A subsequent clinical trial corroborated the results, further demonstrating that six monthly administration of IV CYC $\left(0.5-1.0 \mathrm{~g} / \mathrm{m}^{2}\right)$ then quarterly for 2 years reduced the likelihood of exacerbations compared to those receiving CYC only for the first 6 months. Such treatment is referred to as National Institute of Health (NIH) protocol. ${ }^{15}$

In the mid-1990s, the Euro-Lupus Nephritis Trial (ELNT) was developed, with the hypothesis of obtaining the same efficacy with fewer adverse events. The ELNT protocol consisted in the administration of a low fixed dose of $0.5 \mathrm{~g}$ of IV CYC given every 2 weeks for a cumulative dose of $3 \mathrm{~g}$. Ninety patients were randomized to one of two groups: NIH or ELNT protocol. Both groups received methylprednisolone $750 \mathrm{mg}$ /day for 3 days and prednisone $0.5 \mathrm{mg} / \mathrm{kg} /$ day for 4 weeks with dose reduction, followed by azathioprine as a remission maintenance agent. At 1 year, no differences were found in complete remission, renal flares, or frequency of severe infections. ${ }^{47}$ 
At 10 years, no differences were found regarding survival ( $92 \%$ in both groups), doubling of serum creatinine, and end-stage renal disease; however, severe infections, hematological and gonadal toxicity were less frequent in the low-dose CYC group. ${ }^{48}$

Patients homozygous for CYP2B6*5 or CYP2C19*2 have a higher probability of progressing to terminal nephropathy, doubling serum creatinine, and a lower likelihood of reaching a complete renal response. ${ }^{42}$ GSTA1 polymorphism could lead to an increased risk of drug resistance, increase in adverse events and a higher risk of CYC unresponsiveness. ${ }^{49}$

\section{Mycophenolate Mofetil}

Mycophenolate mofetil (MMF), a fermentation product of Penicillium brevicompactum and related fungi, has an inhibitory effect on the nucleic acids synthesis, an effect known more than 50 years ago. It is a selective, reversible and non-competitive inhibitor of inosine monophosphate dehydrogenase (IMPDH), especially type II isoform which is expressed in activated $\mathrm{B}$ and $\mathrm{T}$ lymphocytes,${ }^{50}$ limiting the de novo synthesis of guanine, preventing its incorporation into DNA, inducing cell arrest in phase $\mathrm{S}$.

During its metabolism, it is extensively hydrolyzed in mycophenolic acid, the bioactive metabolite. Biotransformation is regulated by the cytochrome system: CYP3A4, CYP3A5, and CYP2C8. ${ }^{50}$

Patients with proteinuria more significant than $1 \mathrm{~g} /$ day had lower plasma concentrations and a reduced area on the concentration-time curve (AUC 0-12), compared with patients with proteinuria less than $1 \mathrm{~g}$ /day. Similarly, patients with serum albumin $<4 \mathrm{~g} / \mathrm{dL}$ present increased clearance of the drug. ${ }^{51,52}$

Adverse events occur in more than $50 \%$ of the patients; diarrhea is the most common symptom although it is usually mild; $25 \%$ of the patients require suspension of the drug. The most common infections are urinary tract infections (10\%) and pneumonia (2\%), which usually do not require hospitalization. ${ }^{53,54}$

Its use in $\mathrm{LN}$ is widespread, due to its proven efficacy as induction and remission maintenance agent, with good tolerability, enteral administration, and low gonadal impact, although its main disadvantage is cost.

In 2000, Chan et al compared MMF with CYC for induction therapy in 42 patients with proliferative LN. Patients in the MMF group achieved remission in $81 \%$ vs $76 \%$ in the CYC group (with no statistical significance), and a similar rate of adverse events. ${ }^{55}$ Other studies with a relatively small number of patients had similar results. ${ }^{56,57}$

The ALMS, a controlled, randomized, multicenter study compared MMF with CYC in 370 patients. The combined response, complete or partial, was presented in $56.2 \%$ of the patients in the MMF group vs $53 \%$ in the CYC group. ${ }^{54}$

Most systematic reviews support the use of MMF over CYC ${ }^{58-60}$ although there are studies that favor the use of $\mathrm{CYC}^{61}$ particularly in severe $\mathrm{LN}$, a point to emphasize, since patients with serum creatinine greater than $2.5 \mathrm{mg} / \mathrm{dl}$ are typically excluded from the comparative studies. ${ }^{62}$ In the post-hoc analysis of ALMS, it was found that patients with eGFR less than $30 \mathrm{~mL} / \mathrm{min}$, MMF had the same response compared to CYC ( $20 \%$ vs $16 \%, \mathrm{p}=0.9)$, although weekly recovery of renal function was faster with MMF compared to CYC (1.5 mL/min/week, $95 \%$ CI 0.99 to $2.02, \mathrm{p}<0.001$ ) with no difference in adverse events. ${ }^{63}$ It is important to remark that in class $\mathrm{V} \mathrm{LN}$, MMF and CYC are effective in induction therapy. ${ }^{64}$

MMF is also using a remission maintenance agent. ${ }^{58,65,66}$ The ALMS group also demonstrated during the 36-month follow-up that MMF is superior to azathioprine in terms of therapeutic failure (mortality, requirement for renal replacement therapy, doubling serum creatinine, renal flare, or rescue therapy), observed in $16.4 \%$ of the MMF group compared to $32.4 \%$ in the AZA group. ${ }^{53}$

The dual utility of MMF in induction and maintenance therapy may be associated with down-regulation of plasmablasts and plasma cells, with reduced production of immunoglobulins $\mathrm{M}, \mathrm{A}, \mathrm{G}$ and light chains, predominant in the first weeks of initiating therapy, reflecting the modulation of the immune response on short and long-term; those cellular effects were not detected with CYC. ${ }^{67}$

The ALMS study also demonstrated that MMF was the best choice for remission induction in Hispanic patients. ${ }^{54}$ In a retrospective comparative cohort, which included 165 Hispanic patients with ISN/RPS class III, IV or V LN, MMF was superior to CYC and AZA regarding complete renal response and relapse-free disease. No differences were detected between the groups progressing to endstage renal disease. ${ }^{68}$

MMF is also part of the multitarget protocol as will be seen later in the review. Interestingly, Dall'Era et al in a propensity score methodology, analyzed the ALMS and AURA-LV trials, and concluded that doses of MMF below the recommended target of $2-3 \mathrm{~g} / \mathrm{d}$, especially in induction phase, can be effective (1.9 g/day [AURA-LV] vs $2.6 \mathrm{~g} /$ 
day [ALMS] MMF; mean difference: $-0.76 ; 95 \% \mathrm{CI}$ -0.96 to $-0.57, \mathrm{p}<0.0001),{ }^{69}$ although the clinical relevance should be demonstrated in a randomized clinical trial.

Some authors suggest monitoring MMF concentrations to confirm correct dosing, indicating levels greater than $13 \mathrm{mg} / \mathrm{dL}$ 1-hour post-dose, ${ }^{70}$ while others recommend a threshold of $3 \mathrm{mg} / \mathrm{L}^{71}$

In a very interesting analysis, Hap et al evaluated serum concentrations of mycophenolic acid (MPA) hourly from 1 to 12 hours post-exposure (C1-C12) in 88 stable patients on maintenance treatment; single nucleotide polymorphisms were also evaluated (ABCC2, OATPs and UGT). C1, C2 and C12 concentrations correlated well with $\mathrm{AUC}_{0-12}$. However, only $\mathrm{C} 12$ was associated with infection, anemia and renal flare. The SNP ABCC2, rs2273697 $\mathrm{A} / \mathrm{G}$ was associated with lower exposure to MPA. ${ }^{72}$

Łuszczyńska et al reported that the monitoring of the pre-dose total concentration of MPA shows a correlation, although discrete, with $\mathrm{AUC}_{0-12}(\mathrm{r}=0.57)$, while the monitoring of the concentration of free MPA is more useful in hypoalbuminaemic patients. ${ }^{73}$

Alexander et al also detected that patients with albumin $>3.5 \mathrm{mg} / \mathrm{L}$ reached therapeutic concentrations (AUC $>30 \mathrm{mg} / \mathrm{h} / \mathrm{L}$ ) with greater probability than hypoalbuminaemic patients. ${ }^{74}$ In this study, the initial empirical dose of MPA in the induction treatment was $30 \mathrm{mg} / \mathrm{kg}$ and only $61.8 \%$ reached the mentioned therapeutic concentration. The initial mean dose was $1.5 \mathrm{~g} /$ day and changed to $2 \mathrm{~g} /$ day after measurement. With an AUC $>30 \mathrm{mg} / \mathrm{h} / \mathrm{L}$, a greater renal response was achieved at 1 year (79.4\%).

Both Alexander et al and Pourafshar et al found no association between minimum concentrations $(\mathrm{C} 0)$ and AUC. In this last study, a weak association between $\mathrm{C} 0$ and AUC was detected, since they explained only $30 \%$ of the variability of the minimum concentrations of MPA. Therefore, they suggest that the best method is the evaluation of $\mathrm{AUC}_{0-4}$ for dose monitoring. ${ }^{75}$ Concomitant use of $\mathrm{ACEi} / \mathrm{ARB}$ increased $\mathrm{C} 0$ and $\mathrm{AUC}_{0-4}$ concentrations, while prednisone, diuretics, or hydroxychloroquine did not.

In Japan, an analysis was performed in 10 patients with class III/IV LN, in whom induction treatment with MMF 2 $\mathrm{g} /$ day was started and $\mathrm{AUC}_{0-12}$ was evaluated early (week 4) and intermediate (week 12) with the objective of evaluating the complete renal response (UPCR $<0.5 \mathrm{mg}$ / $\mathrm{g}$ and eGFR variation $<10 \%$ with respect to baseline) at week 12. All patients with $\mathrm{AUC}_{0-12}>40 \mathrm{mg} / \mathrm{h} / \mathrm{L}$ and $33 \%$ of the patients with $\mathrm{AUC}_{0-12}<40 \mathrm{mg} / \mathrm{h} / \mathrm{L}$ in the early evaluation (week 4) had a complete renal response, no association detected with the evaluation intermediate of $\mathrm{AUC}_{0-12}$. In the histological evaluation, there were no differences between the activity and chronicity indices between both groups ( $\mathrm{p}=0.77$ and 0.48 , respectively). ${ }^{76}$ However, the small number of patients does not allow generalization of the results.

In summary, the routine use of MMF concentrations is not currently recommended, but with the new evidence it would be possible to guarantee personalized management of patients with a moderate-to-severe degree of the disease.

\section{Azathioprine}

Azathioprine, synthesized in 1957, is an imidazole derivative, a prodrug metabolized by a non-enzymatic process to mercaptopurine and via glutathione transferase to 6-thioinosinic acid. The liver and erythrocytes eliminate both metabolites. There are two pathways of inactivation of 6-mercaptopurine: first, methylation catalyzed by the enzyme thiopurine methyltransferase (TPMT), which produces the inactive metabolite methyl-6-mercaptopurine; ${ }^{35}$ second, oxidation catalyzed by xanthine oxidase, from which 6-thiopuric acid is generated, this is why patients receiving allopurinol require dose reduction. ${ }^{77}$ Other metabolites include methyl monophosphate-thioinosine, which is incorporated into DNA, blocks replication and purine synthesis, and thioguanosine triphosphate that blocks RNA and induce apoptosis via Bcl signaling. Due to these characteristics, its effect is more intense in lymphocytes in replication.

Adverse events occur in more than $75 \%$ of the patients, requiring dose reduction in $40 \%$ of the cases. However, severe infections requiring hospitalization only occur in $9.5 \%$. The main adverse effects are gastrointestinal, mild infections and cytopenias (thrombocytopenia and leucopenia). ${ }^{53,78,79}$

The severity of symptoms is associated with the genetic polymorphism of TPMT, ${ }^{80}$ especially with three variants: $\mathrm{TPMT}^{*} 2$, TPMT*3A, TMPT*3B, and TPMT*3C. ${ }^{81,82}$ These polymorphisms are present in $10 \%$ of Caucasian, and whose homozygous defect is present in less than $1 \%{ }^{83,84}$

The advantage of this drug is its low cost, good tolerability and it is the recommended drug during pregnancy. ${ }^{85}$

The MAINTAIN study, a clinical trial conducted in 27 European centers, included 105 patients with class III, IV, 
$\mathrm{Vc}$, or Vd LN from the WHO classification who received induction of remission with fortnightly CYC for 3 months and Maintenance therapy with AZA (target dose: $2 \mathrm{mg} / \mathrm{kg} /$ d) or MMF (target dose: $2 \mathrm{~g} / \mathrm{d}$ ) at week 12. Although renal flares were less frequent with MMF, no statistical significance was reached. Proteinuria, serum creatinine, serum levels of complement $\mathrm{C} 3$, hemoglobin and activity scores were similar in the two treatment groups. ${ }^{86}$ At 10 years, renal flares did not differ between groups; death and endstage renal disease were rare events. ${ }^{79}$ This study shows that, in the Caucasian population, MMF is not superior to AZA in long-term outcomes in maintenance therapy.

Therefore, although MMF appears to be more effective than AZA in preventing renal relapse, the data are not entirely conclusive. In a systematic review, Tian et al estimated the probability of 2-year renal failure: $6 \%$ with MMF and $12 \%$ with AZA; however, after applying a skeptical prior in the Bayesian analysis, no benefit of one treatment over another was detected. ${ }^{87}$

From an economic vision, in the short term, AZA appears to be of great value compared with MMF; however, in long-term perspective, MMF seems to be costeffective compared with AZA. ${ }^{88}$

\section{Calcineurin Inhibitors}

Although cyclosporine A (CsA) and tacrolimus (TAC) differ in their molecular structure and intracellular binding characteristics, their immunosuppressive properties result from the inhibition of calcium-calmodulin-calcineurin interaction. ${ }^{89}$ CsA binds to cyclophilin while TAC binds to FKBP12 (formerly FK506), thereby preventing dephosphorylation and translocation of nuclear factor of activated T-cell (NFAT), a relevant step in the synthesis of interleukin 2, a cytokine known for promoting T-cell proliferation. ${ }^{90}$ Because calcineurin is involved in the process of vesicle fusion to the mast cell membrane, calcineurin inhibitors reduce the degranulation of these cells ${ }^{91}$ and inhibit the expression of chemokines in their surface. ${ }^{92}$

Metabolism occurs via CYP3A4 and CYP3A5 in the liver, and at the intestinal level by CYP3A4 and P-glycoprotein (P-gp). They have variable oral bioavailability (10-60\%), so there is an extensive list of pharmacological interactions. ${ }^{93}$ Drugs that increase the bioavailability of CNIs include nondihydropyridine calcium antagonists, azole antifungals, and macrolides; on the other hand, drugs that may reduce their bioavailability include rifampicin, isoniazid, phenytoin, carbamazepine, and trimethoprim/sulfamethoxazole. ${ }^{93}$
Cytochrome $\mathrm{P} 450$ polymorphisms produce individual variations that require dose adjustment because of their association with changes in serum drug levels and increased risk of nephrotoxicity. ${ }^{94}$

ICNs are beneficial drugs with broad efficacy in posttransplant renal patients. Its use has been extended in patients with LN, especially tacrolimus, but also cyclosporine. $^{95}$

Bao et al evaluated the efficacy of multitarget therapy (tacrolimus, mycophenolate, and prednisone) in 40 patients with class IV $+\mathrm{V}$ LN, compared to intravenous CYC, finding remission at 6 months in $50 \%$ versus $5 \%$, respectively. Partial response was present in $40 \%$ in both groups. ${ }^{96}$ Another controlled clinical trial comparing multitarget vs CYC therapy in induction therapy showed that after 24 weeks, $45.9 \%$ of the patients achieved complete remission, compared to $25.6 \%$ of the patients on CYC therapy $(\mathrm{p}<0.001) .{ }^{97}$

In a fascinating study conducted in Japan, multitarget therapy associated with six monthly pulses of CYC was associated with complete remission in $80 \%$ of the patients. ${ }^{98}$

The efficacy of this drug has been corroborated in other studies, most in Asia. ${ }^{99-103}$

Multitarget therapy as maintenance in the LN has also been shown to be superior to azathioprine in renal relapse rates and adverse events. ${ }^{104}$

A good response has been reported in patients with mycophenolate resistance when TAC is added to management, with partial or complete remission reported from $50 \%$ to $70 \%$ of the patients and reduction in requirements of corticosteroids. ${ }^{105-107}$ Combined administration with MMF and CsA also have reported success. ${ }^{108}$

The hypothesis related to the response obtained in refractory cases is related to the overexpression of P-gp in CD4+ $\mathrm{T}$ lymphocytes associated with MDR-1 gene polymorphisms in some patients with lupus; ${ }^{109,110}$ the main function of P-gp is the extrusion of some drugs from the cell membrane. The persistent expression of P-gp can induce resistance to steroids compared with those with reduced expression and function. ${ }^{11,112}$ ICNs are inhibitors of P-gp increasing the sensitivity to other immunosuppressants, particularly steroids, reversing drug resistance. ${ }^{113}$

The most frequent complication with these agents is infection, reported in up to $33 \%$ of the patients, but requiring hospitalization only $6 \%$ of them. ${ }^{106} \mathrm{~A}$ high incidence of cytomegalovirus and herpes zoster infection has been 
reported. $^{101,114}$ Other complications include diarrhea $(12 \%)$, dyspepsia $(6 \%)$, and transient rise in serum creatinine $(6 \%)$, which usually do not require discontinuation of therapy. Serum levels of TAC in the studies are generally between 5 and $8 \mathrm{ng} / \mathrm{mL}$.

An analysis of several controlled clinical trials, TAC proved to be the drug with the highest clinical remission rate, as well as the one with the lowest probability of severe infections compared to MMF, AZA and CYC. ${ }^{17,115,116}$ Therefore, TAC is a good option especially combined with MMF and appears to be superior to achieve remission rates compared to IV CYC. ${ }^{117}$ However, most studies have been conducted in Asian patients, so highquality multi-ethnic clinical trials are required to test its efficacy in different populations. ${ }^{118}$

Voclosporin is a new generation calcineurin inhibitor, with a structure derived from cyclosporin A, its stereoisomer Z-ISA247 binds to cyclophilin A. The higher affinity of voclosporin is explained by van der Waals forces between its only side chain and cyclophilin A. This drug shows greater immunosuppressive activity compared to CsA in vitro and in vivo, in animal models of autoimmunity and transplantation. ${ }^{119}$ In an animal model study with non-human primates, individuals with normal renal function have prescribed a dose of $0.4 \mathrm{mg} / \mathrm{kg}$ (administered with gelatin capsules orally) on day 1 and $0.4 \mathrm{mg} / \mathrm{kg}$ thereafter every third day until the morning of the 10th. Individuals with severe renal failure were prescribed a single dose of $0.4 \mathrm{ng} / \mathrm{kg}$ on day 1 . The maximum concentration on day 1 was $122 \pm 45 \mathrm{ng} / \mathrm{mL}$ and with severe renal failure, $147 \pm 50 \mathrm{ng} / \mathrm{mL}$, this concentration varies, even more, 10 days after administration, with $142 \pm 53 \mathrm{ng} /$ $\mathrm{mL}$, for individuals with normal renal function (urinary excretion in 24 hours [Eu-24] of $107.3 \pm 29.9 \mu \mathrm{g}$ ) and of $184 \mathrm{ng} / \mathrm{mL}$ for individuals with severe renal failure $(\mathrm{Eu}-24$ of 52.8. $\pm 18.6 \mu \mathrm{g})$, despite the difference in the administered dose. ${ }^{120}$

The use of voclosporin in lupus nephritis was carried out in the AURA-LV trial, a multicenter, double-blind, placebo-controlled study to evaluate the usefulness of voclosporin plus the standard of care, MMF, or corticosteroids. In this study, 265 individuals from 20 countries in America, Europe, and Asia were included, 88 individuals were assigned to the placebo group, 89 assigned to low dose VCS (23.7 mg BID), and 88 assigned to high dose VCS (39.5 mg BID), all groups also received standard treatment with MMF $2 \mathrm{~g} / \mathrm{d}$ plus oral corticosteroids. Complete renal remission (CRR) was achieved in $32.6 \%$ of the individuals in the low dose VCS group $(\mathrm{OR}=2.03$; 95\% CI: $1.01-4.05 ; \mathrm{p}=0.046)$ and in $27.3 \%$ of the individuals with high doses of VCS (OR $=1.59 ; 95 \%$ CI: $0.78-3.27$; $=0.204$ ), compared with $19.3 \%$ of the placebo group. VCS doses were superior to placebo for CRR at 48 weeks. Furthermore, the individuals showed a significant change in the decrease in urine protein-tocreatinine ratio (UPCR) and increase in serum albumin. At week 48, anti-dsDNA antibodies decreased $7 \%$ in the placebo group, $51 \%$ in the low-dose VCS group, and $38 \%$ in the high-dose VCS group. The SLE activity presented differences between the groups, at 48 weeks $53.4 \%$ of the patients in the placebo group still had SELENASLEDAI scores $>6$, compared with $29.2 \%$ and $40.9 \%$ in the group of SCV at low and high doses, respectively. Adverse effects reported at week 24 increased in individuals with low doses of VCS (28.1\%), compared with high doses $(25.0 \%)$ and placebo $(15.9 \%)$; the most frequent adverse effect in all groups was infections. This study further demonstrated that the use of VCS in patients with lupus nephritis maintains a significantly higher proportion of CRR at 48 weeks of treatment compared to placebo. ${ }^{23}$

Finally, AURORA trial (NCT03021499) was a 52-week Phase III global, double-blind, placebo-controlled study to evaluate whether VCS when added to background therapy of MMF can increase speed of and overall renal response rates in the presence of low-dose steroids. A total of 357 patients with active LN were enrolled in this study across sites in 27 countries. AURORA met its primary endpoint, achieving statistically superior renal response rates (UPCR of $\leq 0.5 \mathrm{mg} / \mathrm{mg}$, eGFR $\geq 60 \mathrm{~mL} / \mathrm{min}$, or no confirmed decrease from baseline in eGFR of $>20 \%$ ) of $40.8 \%$ for intervention (voclosporin $23.7 \mathrm{mg}$ BID plus MMF $2 \mathrm{~g} /$ day) vs $22.5 \%$ for the control (placebo plus MMF $2 \mathrm{~g}$ /day) (OR $=2.65,95 \%$ CI; p < 0.001). Recently, the US Food and Drug Administration had approved Voclosporin for the treatment of adult patients with active lupus nephritis. Voclosporin significantly demonstrated improvement in renal response rates in AURORA Phase 3 study and the AURA-LV trials. And it is now commercially available in the US.

Tables 1 and 2 summarize the main studies to date for induction and maintenance therapies in lupus nephritis.

\section{Antimalarials}

It is important to note that $40 \%$ to $50 \%$ of the patients will not respond to induction, $38 \%$ will have flares in the course of the disease, and $20 \%$ to $30 \%$ will progress to end-stage renal disease, ${ }^{5}$ so the best treatment is one that 
Table I Main Randomized Clinical Trials in Induction to Remission

\begin{tabular}{|c|c|c|c|c|c|c|c|}
\hline Study & $\begin{array}{l}\text { Patients } \\
\text { (Women) }\end{array}$ & $\begin{array}{c}\text { Lupus } \\
\text { Nephritis } \\
\text { Classification }^{a}\end{array}$ & $\begin{array}{c}\text { Average } \mathbf{C r} \\
\text { or GFR }\end{array}$ & $\begin{array}{c}\text { Average } \\
\text { Proteinuria }\end{array}$ & $\begin{array}{c}\text { Scheme } \\
\text { (Patients) }\end{array}$ & $\begin{array}{c}\text { Follow- } \\
\text { Up }\end{array}$ & Results \\
\hline ELNT $^{47,48}$ & $\begin{array}{l}90 \text { (93\%). } \\
\text { White: } 76 . \\
\text { Black: } 8 . \\
\text { Asian: } 6 .\end{array}$ & $\begin{array}{l}\text { OMS. } \\
\text { III: } 21 \\
\text { IV: } 62 \\
\text { Vc/Vd: } 7\end{array}$ & $1.1 \mathrm{mg} / \mathrm{dl}$ & 3 g/day & $\begin{array}{l}0.5 \mathrm{~g} I V \text { every } 15 \\
\text { days for } 3 \text { months } \\
\text { vs } \\
\text { CYC } 0.5-1 \mathrm{~g} / \mathrm{m}^{2} \\
\text { monthly for } 6 \\
\text { months }\end{array}$ & 10 years & $\begin{array}{l}\text { Therapeutic failure: } 16 \% \\
\text { (low-dose) vs } 20 \% \text { (high- } \\
\text { dose); kidney disease: } \\
27 \% \text { (low-dose) vs } 29 \% \\
\text { (high-dose); end-stage } \\
\text { renal disease: } 5 \% \text { (low- } \\
\text { dose) vs } 9 \% \text { (high-dose). } \\
(p>0.05)\end{array}$ \\
\hline $\begin{array}{l}\text { Ginzler } \\
\text { et al }\end{array}$ & $\begin{array}{l}\text { I } 40 \text { (90\%). } \\
\text { White: } 17 \% . \\
\text { Black: } 56 \% . \\
\text { Asian: } 8 \% . \\
\text { Hispanic: } 19 \% .\end{array}$ & $\begin{array}{l}\text { OMS } \\
\text { III: } 15 \% . \\
\text { IV: } 55 \% . \\
\text { V: } 20 \% . \\
\text { Mixed: } 10 \% .\end{array}$ & $1.0 \mathrm{mg} / \mathrm{dl}$ & $4.2 \mathrm{~g} /$ day & $\begin{array}{l}\text { CYC } 0.5-1 \mathrm{~g} / \\
\mathrm{m}^{2} \text { monthly for } 6 \\
\text { months } \\
\text { vs } \\
\text { MMF } 3 \mathrm{~g} / \text { day }\end{array}$ & 6 months & $\begin{array}{l}\text { Complete response: } \\
22.5 \% \text { (MMF) vs } 5.8 \% \\
(C Y C)(p=0.005) . \text { Partial } \\
\text { response: } 29.6 \% \text { (MMF) } \\
\text { vs } 24.6 \%(C Y C) \\
(p=0.05 \mathrm{I})\end{array}$ \\
\hline $\mathrm{ALMS}^{54}$ & $\begin{array}{l}370 \text { (84.6\%). } \\
\text { White: } 39 \% . \\
\text { Black: } 33 \% . \\
\text { Other: } 72 \% \\
\text { (Hispanic } \\
\text { approx. } 10 \% \text { ). }\end{array}$ & $\begin{array}{l}\text { ISN/RPS } \\
\text { III or III + V: } \\
\text { I5.7\% } \\
\text { IV or IV + V: } \\
68.1 \% \\
\text { V: } 16.2 \%\end{array}$ & $\mathrm{I} . \mathrm{l} \mathrm{mg} / \mathrm{dl}$ & $4.1 \mathrm{~g} /$ day & $\begin{array}{l}\mathrm{CYC} 0.5-1 \mathrm{~g} / \mathrm{m}^{2} \\
\text { monthly for } 6 \\
\text { months } \\
\text { vs } \\
\text { MMF } 3 \mathrm{~g} / \text { day }\end{array}$ & 6 months. & $\begin{array}{l}\text { Complete/partial } \\
\text { response: } 56.2 \% \text { vs } 53 \% \\
\text { ( }>0.05 \text { ). } \\
\text { Black and Hispanic } \\
\text { ethnicity show a better } \\
\text { response. }\end{array}$ \\
\hline $\begin{array}{l}\text { ALMS } \\
\text { sub- } \\
\text { analysis }^{63}\end{array}$ & $\begin{array}{l}32(86 \%) . \\
\text { White: } 51 \% . \\
\text { Asian: } 26 \% . \\
\text { Other: } 23 \% .\end{array}$ & $\begin{array}{l}\text { ISN/RPS } \\
\text { III or III + V: } \\
\text { I7.5\% } \\
\text { IV or IV + V: } \\
82.5 \%\end{array}$ & $\begin{array}{l}\text { GFR: } \\
24 \mathrm{~mL} / \mathrm{min}\end{array}$ & $4.3 \mathrm{~g} / \mathrm{day}$ & $\begin{array}{l}\text { CYC } 0.5-1 \mathrm{~g} / \mathrm{m}^{2} \\
\text { monthly for } \\
\text { months } \\
\text { vs } \\
\text { MMF } 3 \mathrm{~g} / \text { day }\end{array}$ & 24 weeks & $\begin{array}{l}\text { Response: } 20 \% \text { (MMF) } \\
\text { vs } 16.7 \%(C Y C)(H R \\
\text { I.2, } p=0.9) . \\
\text { Recovery GFR: I. } 51 \mathrm{~mL} / \\
\text { min/week. Faster with } \\
\text { MMF ( } p<0.00 \mathrm{I}) .\end{array}$ \\
\hline $\begin{array}{l}\text { AURA- } \\
\mathrm{LV}^{23}\end{array}$ & $\begin{array}{l}230 \text { (86.8\%) } \\
\text { White: } 40.8 \% \\
\text { Black: } 5.3 \% \\
\text { Asian-Indian: } \\
22.6 \% \\
\text { Asian: } 27.2 \% \\
\text { Other: } 4.2 \%\end{array}$ & $\begin{array}{l}\text { ISN/RPS } \\
\text { V: } 14.7 \% \\
\text { III or IV: } 67 \% \\
\text { III + V or IV + V: } \\
\text { I8. } 1 \%\end{array}$ & $\begin{array}{l}\text { GFR: } \\
99.8 \mathrm{~mL} / \mathrm{min}\end{array}$ & $\begin{array}{l}\text { Urine } \\
\text { protein-to- } \\
\text { creatinine } \\
\text { ratio: } 4.69 \mathrm{~g} / \mathrm{g}\end{array}$ & $\begin{array}{l}\text { Voclosporin low } \\
\text { dose: } 23.7 \mathrm{mg} \text { BID + } \\
\text { MMF } 2 \mathrm{~g} / \mathrm{d}+ \\
\text { corticosteroids or } \\
\text { high dose: } 39.5 \mathrm{mg} \\
\text { BID + MMF } 2 \mathrm{~g} / \mathrm{d}+ \\
\text { corticosteroids } \\
\text { vs } \\
\text { placebo + MMF } 2 \text { g/d } \\
+ \text { corticosteroids }\end{array}$ & 24 weeks & $\begin{array}{l}\text { CRR: low dose } 32.6 \% \\
(O R=2.03, p=0.046) \text {, } \\
\text { high dose: } 27.3 \%(O R= \\
\text { I.59, } p=0.204) \text { vs } \\
\text { placebo: } 19.3 \%\end{array}$ \\
\hline $\begin{array}{l}\text { Furie } \\
\text { et al }{ }^{165}\end{array}$ & $\begin{array}{l}393(88 \%) \\
\text { Asian: } 50 \% \\
\text { White: } 33 \% \\
\text { Black: } 14 \% \\
\text { Other: } 3 \%\end{array}$ & $\begin{array}{l}\text { ISN/RPS } \\
\text { III or IV: } 58 \% \\
\text { III + Vor IV + V: } \\
26 \% \\
\text { V: } 16 \%\end{array}$ & $\begin{array}{l}\text { GFR: } \\
100.5 \mathrm{~mL} / \mathrm{min}\end{array}$ & $\begin{array}{l}\text { Urine } \\
\text { protein-to- } \\
\text { creatinine } \\
\text { ratio: } 3.4 \mathrm{~g} / \mathrm{g}\end{array}$ & $\begin{array}{l}\text { Belimumab } 10 \mathrm{mg} / \\
\mathrm{kg} \text { at day I, I5, } 29 \\
\text { and every } 28 \text { days } \\
\text { to week } 100 \\
\text { vs } \\
\text { placebo }\end{array}$ & I04 weeks & $\begin{array}{l}\text { Primary efficacy renal } \\
\text { response: Belimumab } \\
43 \% \text { vs placebo } 32 \% \\
(\text { OR I.6, p }=0.03 \text { ) }\end{array}$ \\
\hline
\end{tabular}

Notes: ${ }^{a}$ Histopathological classification of the World Health Organization (WHO). International Society of Nephrology/Society of Nephrologists (ISN/RPS).

Abbreviations: Cr, creatinine; GFR, glomerular filtration rate; CYC, cyclophosphamide; MMF, mycophenolate mofetil. 
Table 2 Main Randomized Clinical Trials in Maintenance of Remission

\begin{tabular}{|c|c|c|c|c|c|c|c|}
\hline Study & $\begin{array}{l}\text { Patients } \\
\text { (Women) }\end{array}$ & $\begin{array}{c}\text { Lupus } \\
\text { Nephritis }^{\text {Classification }}\end{array}$ & $\begin{array}{l}\text { Average } \\
\text { Creatinine }\end{array}$ & $\begin{array}{c}\text { Average } \\
\text { Proteinuria }\end{array}$ & $\begin{array}{l}\text { Induction to } \\
\text { Remission }\end{array}$ & $\begin{array}{c}\text { Maintenance } \\
\text { Dose } \\
\text { (Patients) }\end{array}$ & Results \\
\hline MAINTAIN ${ }^{86}$ & $\begin{array}{l}105 \text { (91\%). } \\
\text { White: } \\
79 \% . \\
\text { Black: } 12 \% . \\
\text { Asian: } 9 \% .\end{array}$ & $\begin{array}{l}\text { OMS. } \\
\text { III: } 31 \% \\
\text { IV: } 58 \% \\
\text { Vc: } 3 \% \\
\text { Vd: } 8 \%\end{array}$ & $1.0 \mathrm{mg} / \mathrm{dL}$ & $\begin{array}{l}2.94 \mathrm{~g} / \text { day } \\
(\mathrm{AZA}) \\
3.63 \mathrm{~g} / \text { day } \\
\text { (MMF) }\end{array}$ & $\begin{array}{l}\text { CYC } 0.5 g \text { IV every } \\
\text { I } 5 \text { days for } 3 \\
\text { months. }\end{array}$ & $\begin{array}{l}\text { AZA } 2 \mathrm{mg} / \mathrm{kg} / \\
\text { day. } \\
\text { Vs } \\
\text { MMF } 2 \mathrm{~g} / \text { day. }\end{array}$ & $\begin{array}{l}\text { Kidney disease: } 19 \% \\
\text { (MMF) vs } 25 \%(A Z A) \\
\text { (HR: } 0.75, p=0.48)\end{array}$ \\
\hline $\mathrm{ALMS}^{53}$ & $\begin{array}{l}227 \text { (86\%). } \\
\text { White: } \\
44 \% . \\
\text { Black: 10\%. } \\
\text { Asian: 33\% } \\
\text { Hispanic: } \\
\text { I3\% }\end{array}$ & $\begin{array}{l}\text { ISN/RPS. } \\
\text { III ○ IV + V: } \\
\text { I3\%. } \\
\text { IV } \text { IV + V: } 72 \% \\
\text { V: } 15 \%\end{array}$ & $0.86 \mathrm{mg} / \mathrm{dL}$ & $\begin{array}{l}0.82 \mathrm{~g} / \text { day } \\
(\mathrm{AZA}) \\
0.90 \mathrm{~g} / \text { day } \\
(\mathrm{MMF})\end{array}$ & $\begin{array}{l}\text { CYC } 0.5 \text { a I g/m² } \\
\text { monthly for } 6 \\
\text { cycles vs MMF } 3 \\
\text { g/day. }\end{array}$ & $\begin{array}{l}\text { AZA } 2 \text { mg/kg/ } \\
\text { day. } \\
\text { vs } \\
\text { MMF 2g/day. }\end{array}$ & $\begin{array}{l}\text { Treatment failure } \\
16.4 \% \text { (MMF) vs } 32.4 \% \\
\text { (AZA). } \\
\text { (HR:0.44, } P=0.003 \text { ). }\end{array}$ \\
\hline
\end{tabular}

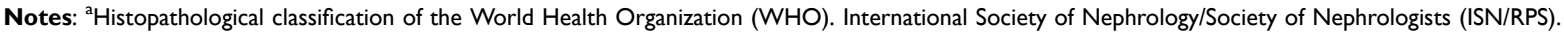
Abbreviations: MMF, mycophenolate mofetil; AZA, azathioprine; CYC, cyclophosphamide.

prevents the development of flares. Among them, antimalarials are drugs of proven efficacy.

Hydroxychloroquine (HCQ) and chloroquine (CQ) are 4-aminoquinolines. They are well absorbed, with $80 \%$ bioavailability after oral administration and half-life of 40 days. ${ }^{121}$ They have hepatic metabolism and renal excretion. The onset of its anti-inflammatory effect takes between 4 and 6 weeks, while the time to reach stable concentrations in blood is estimated between 4 and 6 months. ${ }^{122}$

These agents can suppress the antigen presentation, inhibit the synthesis of prostaglandins, cytokines, and influence both Toll-like receptor signaling and lymphocyte differentiation, ${ }^{123-125}$ as well as improving the Treg cell balance, ${ }^{126}$ with other proven pleiotropic effects that include improving proteinuria ${ }^{127,128}$ and reduce accelerated atherosclerosis frequent in patients with SLE. ${ }^{129}$

The relationship of pro- and anti-inflammatory serum cytokines in lupus has been evaluated; a reduced IL-10/ TNF-alpha ratio could be related to a reduction in the percentage of CD4+ CD25+ regulatory cells (Treg). Antimalarials appear to be especially beneficial in patients with this inflammatory profile. ${ }^{130,131}$

Due to the lipophilic and lysomotropic nature of the HCQ, it can easily cross through the cell membrane. In the cytoplasm, the free base accumulates within the lysosomes; these have high acid content generated by the activity of the hydrogen ATPase-V. High concentrations of HCQ raise the lysosomal $\mathrm{pH}$, from 4.7 to 6 . The intralysosomal alkalization results in its expansion and vacuolation, interfering with the enzymatic release, receptor recycling, and repair of its membrane. ${ }^{132}$

Antimalarials are inhibitors of P-gp, so they have the potential to reduce drug resistance of autoreactive T lymphocytes. ${ }^{133}$

An additional benefit is that these therapeutic agents can be used during pregnancy. ${ }^{85}$

At recommended doses, the toxicity is up to $2 \%$ after 10 years of treatment, and up to $20 \%$ after 20 years of treatment. ${ }^{134}$ The exact mechanism by which antimalarial drugs cause retinal toxicity is not well elucidated, however studies in animal models suggest that the damage in lysosomal function produces an accumulation of lipofuscin, ${ }^{135}$ which is toxic to photoreceptors and retinal pigment epithelium cells (RPE), where HCQ is deposited 20,000 times above blood levels. ${ }^{136}$ Seven percent of the patients with CQ and $0.6 \%$ of the patients with HCQ will have corneal deposits. Other adverse effects are headaches $(12 \%)$, gastrointestinal disturbances $(15 \%)$ and ototoxicity $(0.5 \%)$.

Current recommendations advise testing within the first 6 months of treatment and annually if there are clinical findings suggestive of imminent toxicity (major risk factors), or yearly after 5 years of continuous therapy. ${ }^{134}$ Unfortunately, there is poor adherence to the recommendations, less than $20 \%$ of the clinicians are aware of ophthalmologic assessment recommended by the clinical guidelines. $^{136}$ 
The major risk factors for retinal toxicity: $>5$ years of use (assuming no other risk factors), high daily doses ( $>400 \mathrm{mg}$ or $5 \mathrm{mg} / \mathrm{kg} /$ day of HCQ and $>250 \mathrm{mg}$ or $2.3 \mathrm{mg} / \mathrm{kg} /$ day of CQ), concomitant use of tamoxifen, subnormal glomerular filtration rate, and preexisting visual impairment (retinopathy or maculopathy). It is recommended that the dose does not exceed $5 \mathrm{mg} / \mathrm{kg} /$ day, taking as reference the ideal weight of the patient. ${ }^{134}$

Different observational studies are described in Table 3.

\section{Rituximab}

CD20 is a member of the family of integral membrane proteins, expressed during cell differentiation from pro-B cell to a plasma cell. CD 20 regulates the activation process of cell cycle and differentiation. In vitro, a role for $\mathrm{CD} 20$ as a calcium channel is proposed. ${ }^{137}$ It has been demonstrated that patients with CD20 deficiency exhibit independent T-cell immunodeficiency. ${ }^{138}$ RTX is a murine/ human unconjugated chimeric monoclonal antibody, consisting of two heavy chains of 451 amino acids and two light chains of 213 amino acids with a molecular weight of $145 \mathrm{kD}$. The vector was cloned into Chinese hamster ovary cells as a source of immunoglobulin production. ${ }^{139}$

The Fc portion is responsible for the multiple mechanisms of action related to RTX including complement-dependent cytotoxicity (CDC), antibody-dependent cellular cytotoxicity (ADCC), and antibody-dependent cellular phagocytosis (ADCP). Many immune cells, including NK, macrophages, and monocytes, eliminate anti-CD20-labeled B cells. ${ }^{140,141}$

Table 3 Studies Involving the Use of Antimalarials in Systemic Lupus Erythematosus

\begin{tabular}{|c|c|c|c|}
\hline Study & Patients & $\begin{array}{l}\text { Primary } \\
\text { Outcome }\end{array}$ & Results \\
\hline $\begin{array}{l}\text { Tsakonas } \\
\text { et al }\end{array}$ & $\begin{array}{l}47 . \\
-25 \mathrm{HCQ} \\
-22 \text { placebo }\end{array}$ & Flares & $\begin{array}{l}\text { Protection against the occurrence of kidney disease }(R R=0.26 ; 95 \% \\
C l: 0.03-2.54, p=0.025) \text {. }\end{array}$ \\
\hline $\begin{array}{l}\text { Fessler } \\
\text { et al }\end{array}$ & $\begin{array}{l}518 \text { ( } 34 \% \text { Hispanic) } \\
-29 I \text { with HCQ } \\
-227 \text { without HCQ }\end{array}$ & $\begin{array}{l}\text { Systemic damage } \\
\text { accumulation }\end{array}$ & $\begin{array}{l}\text { Reduced risk of accumulated kidney damage }(\mathrm{HR}=0.68 ; 95 \% \mathrm{Cl} \text { : } \\
0.53-0.93, \mathrm{p}=0.014) \text {. }\end{array}$ \\
\hline $\begin{array}{l}\text { Ruiz- } \\
\text { Irastorza } \\
\text { et } \text { al }^{171}\end{array}$ & $\begin{array}{l}232 \\
-62 \mathrm{HCQ} \\
-46 \mathrm{CQ} \\
-42 \mathrm{HCQ} \text { and } \mathrm{CQ} \\
-82 \text { without antimalarial }\end{array}$ & Survival & $\begin{array}{l}\text { Increased I5-years cumulative survival in antimalarial users } \\
\text { compared to non-users }(0.95 \text { vs } 0.68, p<0.001) \text {. }\end{array}$ \\
\hline Sisó et al $\left.\right|^{172}$ & $\begin{array}{l}206 \\
-56 \mathrm{HCQ} \text { or } \mathrm{CQ} \text { prior to the lupic } \\
\text { nephropathy diagnosis } \\
-150 \text { controls prior to the lupic } \\
\text { nephropathy diagnostic }\end{array}$ & $\begin{array}{c}\text { Systemic } \\
\text { complications }\end{array}$ & $\begin{array}{l}\text { Increased creatinine greater than } 4 \mathrm{mg} / \mathrm{dL}: 2 \%(\mathrm{HCQ} \text { or } \mathrm{CQ}) \text { vs } \mathrm{II} \% \\
\text { (control) }(\mathrm{p}=0.029) \text {. } \\
\text { Terminal nephropathy: } 2 \%(\mathrm{HCQ} \text { or } \mathrm{CQ}) \text { vs } \mathrm{II} \% \text { (control) }(\mathrm{p}= \\
0.044) \text {. }\end{array}$ \\
\hline $\begin{array}{l}\text { Pons-Estel } \\
\text { et } \mathrm{al}^{173}\end{array}$ & $\begin{array}{l}203 \text { (39\% Hispanic) } \\
-161 \mathrm{HCQ} \\
-42 \text { without HCQ }\end{array}$ & Nephroprotection & $\begin{array}{l}\text { Reduced risk of nephropathy in } \mathrm{HCQ} \text { users }(\mathrm{HR}=0.29 ; 95 \% \mathrm{Cl} \text { : } \\
0.13-0.68, \mathrm{p}=0.0043) \text {. } \\
\text { Cumulative probability of } 20 \% \text { kidney damage within } 5 \text { years }(\mathrm{HCQ}) \\
\text { vs } 47 \% \text { (control) }(\mathrm{p}<0.00 \mathrm{I}) \text {. }\end{array}$ \\
\hline $\begin{array}{l}\text { Shinjo } \\
\text { et al }\end{array}$ & $\begin{array}{l}\text { I } 480 \text { (Latin American) } \\
\text { - I I4I HCQ or CQ } \\
\text { - } 339 \text { without antimalarial }\end{array}$ & Mortality & $38 \%$ reduction in mortality rate $(\mathrm{HR}=0.62 ; 95 \% \mathrm{Cl}: 0.39-0.99)$. \\
\hline $\begin{array}{l}\text { Pons-Estel } \\
\text { et } \text { al }^{175}\end{array}$ & $\begin{array}{l}795 . \\
\text { (Latin American) } \\
-265 \text { with nephropathy. } \\
-530 \text { without nephropathy }\end{array}$ & Nephroprotection & $\begin{array}{l}\text { Reduced risk of nephropathy in control group vs clinical cases (OR } \\
0.38 \text {; IC } 95 \%: 0.25-0.58 \text { ). }\end{array}$ \\
\hline
\end{tabular}

Abbreviations: $\mathrm{HCQ}$, hydroxychloroquine; $\mathrm{CQ}$, chloroquine. 
The half-life is 59.8 hours (ranged from 11.1 to 104.6 hours) after the first infusion and 174 hours (range from 26 to 442 hours) after the fourth infusion. The half-life is increased to 10 to 14 days in patients with renal disease. ${ }^{142}$ RTX persists in the circulation for 3 to 6 months and is not eliminated by conventional hemodialysis. ${ }^{143}$

The LUNAR study ${ }^{144}$ evaluated 144 patients with class III or IV LN; patients were randomized to receive an intravenous infusion of placebo or $1 \mathrm{~g}$ of RTX at 0,2 , 24 and 26 weeks. All patients received three boluses of 1 $\mathrm{g}$ methylprednisolone, mycophenolate $1 \mathrm{~g}$ three times a day, and prednisone. At week 52, it showed that the incidence of complete or partial response was numerically higher with RTX but without statistical significance. However, there were further reductions in anti-DNA titers and improvements in complement levels with RTX. The frequency of infections and hospitalizations was similar compared to placebo. Therefore, the use of RTX as induction therapy for proliferative varieties was not supported.

However, some experts argue that the positive effect of RTX may have been diluted by the concomitant use of high doses of MMF. Interestingly, the subgroup of Hispanic and African American patients benefited most from therapy. ${ }^{145}$ The dose commonly used in $\mathrm{LN}$ ranges from $375 \mathrm{mg} / \mathrm{m}^{2}$ weekly for 4 weeks to 2 doses of $1 \mathrm{~g}$ every 2 weeks. ${ }^{146}$

As mentioned, the RITUXILUP trial evaluates the effect of two doses of rituximab, MMF and MTP, without oral prednisone. The response was obtained in almost $90 \%$ of the patients: complete remission in $52 \%$ and partial remission in $34 \%$ at 37 weeks. $^{21}$

Interestingly, Gomez Mendez et al as part of a subanalysis of LUNAR trial found that the achievement of complete peripheral depletion was statistically associated with renal response, with an odds ratio of $5.8(95 \% \mathrm{CI}$ : $1.2-28 ; \mathrm{p}=0.03) .{ }^{147}$

The most common adverse events of RTX are related to the first application. These include headache, nausea, urticaria, and hyper- or hypotension. These reactions, which rarely appear to be dangerous, may decrease with glucocorticoid premedication.

There is greater susceptibility to acute or late-onset neutropenia, and infections (mainly pneumonia). ${ }^{148,149}$ Low IgG levels $(<6 \mathrm{~g} / \mathrm{L})$ before RTX can predispose to severe infections, especially in the first 3 months following RTX infusion ${ }^{150}$; other risk factors are diabetes, cumulative RTX dose, and the use of AZA. ${ }^{148}$ Vaccination with live virus is not recommended after RTX. ${ }^{143}$ A hepatitis
B virus serologic profile before RTX is significant as the virus can reactivate with the monoclonal antibody. ${ }^{151}$

One of the most severe complications is progressive multifocal leukoencephalopathy (PML), probably caused by reactivation of the $\mathrm{JC}$ virus. ${ }^{152,153}$ In one study, the viral prevalence in peripheral blood mononuclear cells, serum, and urine samples was $2.4 \%, 0 \%$, and $50 \%$, respectively, in the healthy donors, and $26 \%, 16 \%$, and $86 \%$, respectively, in the patients treated with RTX. ${ }^{154}$

Another cause of concern is the development of antichimeric antibodies against RTX, although its clinical relevance in SLE patients should be determined. ${ }^{155-157}$

\section{Belimumab}

Belimumab is a monoclonal antibody, an IgG1 $\lambda$ immunoglobulin directed against BLyS, also known as the B-cell activating factor (BAFF). BAAF is a member of the tumor necrosis factor (TNF) superfamily of cytokines, it binds to three different receptors: the transmembrane activator and calcium-modulator, and cyclophilin ligand interactor (TACI), B cell maturing antigen, and BLyS Receptor type 3 (BR3). ${ }^{158}$ Inhibition of BAAF, which is overexpressed in SLE, ${ }^{159}$ promotes apoptosis and decreases B cell survival, thus making it an important therapeutic agent. Belimumab has a mean initial volume of distribution of $40-57 \mathrm{~mL} / \mathrm{kg}$, a distribution phase half-life of 12.2 days, and a terminal elimination half-life of 8.5-14.1 days. Clearance is $7 \mathrm{~mL} / \mathrm{kg}$ /day after administration of a single dose. ${ }^{160}$

The main adverse events are infections; however, the risk remains stable in patients after 7 years of follow-up. Other documented adverse effects are hypersensitivity, headache, nausea, fatigue, and $16 \%$ of the patients have psychiatric adverse effects. ${ }^{161,162}$

Belimumab was evaluated in two phase III clinical trials, comparing belimumab at doses of 1 and $10 \mathrm{mg} / \mathrm{kg}$ plus standard therapy and placebo plus standard therapy in patients with SLE and positive autoantibodies. The BLISS52 trial was conducted in Asia, Europe, and South America with a 52-week follow-up, and BLISS-76 was conducted in North America and Europe with a 76-week follow-up. The administration of the medications was carried out on days 0 , 14, and 28 and then every 28 days until 48 weeks. Efficacy at week 52 was evaluated by SRI (SLE Respond Index), defined as a reduction of $\geq 4$ points in the SELENA-SLEDAI score. In the belimumab group at $10 \mathrm{mg} / \mathrm{kg}$, there was a better response compared with placebo $(43.2 \%$ versus $33.5 \% ; \mathrm{p}=0.017)$, the response rate in the $1 \mathrm{mg} / \mathrm{kg}$ 
belimumab group (40.6\%) was also higher than in the placebo group $(p=0.089)$. SRI response rates at 76 weeks were higher in the group of belimumab at $10 \mathrm{mg} / \mathrm{kg}(38.5 \%)(\mathrm{p}=$ $0.13)$ and belimumab at $1 \mathrm{mg} / \mathrm{kg}(39.1 \%)(\mathrm{p}=0.11)$ compared with placebo (32.4\%). ${ }^{163,164}$

Furie et $\mathrm{al}^{165}$ conducted a phase III trial in 21 countries in which 228 patients diagnosed with biopsy-proven lupus nephritis received intravenous belimumab at a dose of $10 \mathrm{mg} / \mathrm{kg}$ in addition to standard therapy and were compared with 224 patients who received placebo and standard therapy. The response in the improvement of renal function was evaluated with a urinary protein-to-creatinine ratio (UPCR) $\leq 0.7 \mathrm{mg} / \mathrm{g}$, eGFR ( $<20 \%$ deterioration with respect to baseline creatinine prior to kidney disease), and absence of rescue treatment. At week 104, patients in the belimumab group had a better response in renal function compared to the placebo group (96 of 223 patients [43\%] versus 72 of 223 [32\%]; OR=1.6; 95\% CI: $1.0-2.3 ; \mathrm{p}=$ 0.03 ). Time to efficacy at 52 weeks was also longer in the belimumab group compared to patients in the placebo group (104 of 223 patients [47\%] versus 79 of 223 patients [35\%]; OR $=1.6 ; 95 \%$ CI: $1.1-2.4 ; \mathrm{p}=0.02$ ).

Atisha-Fregoso et al ${ }^{166}$ enrolled 43 adults with recurrent or refractory LN (Class III, IV alone or in combination with class $\mathrm{V}$ ) and randomized 1:1 to receive belimumab or placebo after treatment with RTX plus CYC. All patients had been treated with either CYC or MMF in the past. At week 48 , a complete or partial renal response occurred in $11(52 \%)$ of 21 patients receiving belimumab, compared to $9(41 \%)$ of 22 patients in the group who did not receive belimumab $(\mathrm{p}=$ 0.452). Lack of improvement in or worsening of LN was the major reason for treatment failure. B cell depletion occurred in both groups, but the percentage of $\mathrm{B}$ cells remained lower in those receiving belimumab $(p=0.0012)$.

Thus, belimumab has been shown to be effective in the induction treatment phase in combination with mycophenolate, reducing the steroid dose and the risk of progression to end-stage chronic kidney disease. ${ }^{167}$

\section{Ongoing Clinical Trials}

Among others, obinutuzumab, a third-generation type II antiCD20 antibody, has recently been evaluated as a potential treatment for lupus nephritis. A multicentric trial with obinutuzumab (NOBILITY) has been evaluating the safety and efficacy of this drug in participants who receive obinutuzumab $1000 \mathrm{mg}$ intravenous infusion on Days 1,15, 168, and 182 along with mycophenolate mofetil or mycophenolic acid. They found that $34 \%(\mathrm{p}=0.1145)$ of patients achieved complete renal response, and 55\% $(\mathrm{p}=0.0150)$ achieved a partial response at week 52 [ClinicalTrials.gov: NCT02550652].

Abatacept is a fusion protein that selectively modulates $\mathrm{s}$ molecular interaction between antigen-presenting cells (APC) and $\mathrm{T}$ lymphocytes is essential for the optimal activation of the immunological response and requires the participation of two membrane receptors, CD80 and CD86. Recently, 695 participants were enrolled in a trial (ALLURE) comparing Abatacept $30 \mathrm{mg} / \mathrm{kg}$ vs placebo. They did not find a significant difference when treating patients with abatacept vs placebo, $35 \%$ vs $33.5 \%$ ( $p=$ 0.7264), but those who received abatacept appeared to show more rapid and more sustained proteinuria reduction [ClinicalTrials.gov: NCT01714817].

Ocrelizumab (OCR), a humanized monoclonal antibody directed against the B-cell CD20 cell surface antigen, with immunosuppressive activity has been evaluated in patients who received OCR $400 \mathrm{mg}, 1000 \mathrm{mg}$ or placebo. In this trial (BELONG) $42.7 \%, 31.5 \%$ and $34.7 \%$ of the participants achieved a complete renal response at week 48 [ClinicalTrials.gov: NCT00626197].

\section{Limitations}

The present review is exhaustive, but it is not feasible to compile information that constantly appears in the medical literature. It is possible that evidence with preliminary reports of effectiveness in lupus nephritis has not been included. However, we believe that the compilation and evaluation of the information available up to the time of publication of this review will provide a well-documented overview in the treatment of lupus nephritis.

\section{Conclusions}

Lupus nephritis remains one of the most serious complications of systemic lupus erythematosus, and its early detection is essential to provide the best available treatment. Currently, there are several management alternatives, both in the remission induction phase and in the maintenance phase. Mycophenolate mofetil remains the mainstay of treatment, but cyclophosphamide is a less expensive option and perhaps more effective in severe kidney injury. Rituximab is an option that is still under study, although it is currently reserved for resistant cases. Calcineurin inhibitors are an excellent alternative, especially voclosporin, recently approved by the FDA. Other agents like belimumab offer promising results. Ongoing clinical studies will determine whether immunosuppression options in lupus nephritis are extended. 


\section{Acknowledgments}

The authors thank Dr Luis Estrada-Loyo, Dr Ernesto Roldan-Valadez and Dr Julio Casasola-Vargas for their support for the literature search and writing style.

\section{Disclosure}

The authors of this review declare no conflicts of interest for this work.

\section{References}

1. Pakozdi A, Pyne D, Sheaff M, Rajakariar R. Utility of a repeat renal biopsy in lupus nephritis: a single centre experience. Nephrol Dial Transplant. 2018;33(3):507-513. doi:10.1093/ndt/ gfx019

2. Kon T, Yamaji K, Sugimoto K, et al. Investigation of pathological and clinical features of lupus nephritis in 73 autopsied cases with systemic lupus erythematosus. Mod Rheumatol. 2010;20 (2):168-177. doi:10.3109/s10165-009-0260-3

3. Borchers AT, Leibushor N, Naguwa SM, Cheema GS, Shoenfeld Y, Gershwin ME. Lupus nephritis: a critical review. Autoimmun Rev. 2012;12(2):174-194. doi:10.1016/j. autrev.2012.08.018

4. Adler M, Chambers S, Edwards C, Neild G, Isenberg D. An assessment of renal failure in an SLE cohort with special reference to ethnicity, over a 25-year period. Rheumatology (Oxford). 2006;45(9):1144-1147. doi:10.1093/rheumatology/kel039

5. Quintana LF, Jayne D. Sustained remission in lupus nephritis: still a hard road ahead. Nephrol Dial Transplant. 2016;31 (12):2011-2018. doi:10.1093/ndt/gfv381

6. Mahajan A, Amelio J, Gairy K, et al. Systemic lupus erythematosus, lupus nephritis and end-stage renal disease: a pragmatic review mapping disease severity and progression. Lupus. 2020;29 (9):1011-1020. doi:10.1177/0961203320932219

7. Sabucedo AJ, Contreras G. ESKD, transplantation, and dialysis in lupus nephritis. Semin Nephrol. 2015;35(5):500-508 doi:10.1016/j.semnephrol.2015.08.011

8. Zhang L, Lee G, Liu X, et al. Long-term outcomes of end-stage kidney disease for patients with lupus nephritis. Kidney Int. 2016;89(6):1337-1345. doi:10.1016/j.kint.2016.02.014

9. Hench PS, Kendall EC, Slocumb CH, Polley HF. The effect of a hormone of the adrenal cortex (17-hydroxy-11dehydrocorticosterone; compound E) and of pituitary adrenocorticotropic hormone on rheumatoid arthritis. Proc Staff Meet Mayo Clin. 1949;24(8):181-197.

10. Scheschowitsch K, Leite JA, Assreuy J. New insights in glucocorticoid receptor signaling-more than just a ligand-binding receptor. Front Endocrinol (Lausanne). 2017;8:16. doi:10.3389/ fendo.2017.00016

11. Cain DW, Cidlowski JA. Immune regulation by glucocorticoids Nat Rev Immunol. 2017;17(4):233-247. doi:10.1038/nri.2017.1

12. Hardy RS, Raza K, Cooper MS. Therapeutic glucocorticoids: mechanisms of actions in rheumatic diseases. Nat Rev Rheumatol. 2020;16(3):133-144. doi:10.1038/s41584-020-0371-y

13. Vandewalle J, Luypaert A, De Bosscher K, Libert C. Therapeutic mechanisms of glucocorticoids. Trends Endocrinol Metab. 2018;29(1):42-54. doi:10.1016/j.tem.2017.10.010

14. Buttgereit F, Wehling M, Burmester GR. A new hypothesis of modular glucocorticoid actions: steroid treatment of rheumatic diseases revisited. Arthritis Rheum. 1998;41(5):761-767. doi:10.1002/1529-0131(199805)41:5<761::AID-ART2>3.0 $\mathrm{CO} ; 2-\mathrm{M}$
15. Boumpas DT, Austin HA, Vaughn EM, et al. Controlled trial of pulse methylprednisolone versus two regimens of pulse cyclophosphamide in severe lupus nephritis. Lancet. 1992;340 (8822):741-745. doi:10.1016/0140-6736(92)92292-N

16. Gourley MF, Austin HA, Scott D, et al. Methylprednisolone and cyclophosphamide, alone or in combination, in patients with lupus nephritis. A randomized, controlled trial. Ann Intern Med. 1996;125 (7):549-557. doi:10.7326/0003-4819-125-7-199610010-00003

17. Singh JA, Hossain A, Kotb A, Wells G. Risk of serious infections with immunosuppressive drugs and glucocorticoids for lupus nephritis: a systematic review and network meta-analysis. $B M C$ Med. 2016;14(1):137. doi:10.1186/s12916-016-0673-8

18. Walsh M, Jayne D, Moist L, Tonelli M, Pannu N, Manns B. Practice pattern variation in oral glucocorticoid therapy after the induction of response in proliferative lupus nephritis. Lupus. 2010;19(5):628-633. doi:10.1177/0961203309356292

19. Fischer-Betz R, Chehab G, Sander O, et al. Renal outcome in patients with lupus nephritis using a steroid-free regimen of monthly intravenous cyclophosphamide: a prospective observational study. J Rheumatol. 2012;39(11):2111-2117. doi:10.3899/jrheum.120537

20. Zeher M, Doria A, Lan J, et al. Efficacy and safety of enteric-coated mycophenolate sodium in combination with two glucocorticoid regimens for the treatment of active lupus nephritis. Lupus. 2011;20 (14):1484-1493. doi:10.1177/0961203311418269

21. Condon MB, Ashby D, Pepper RJ, et al. Prospective observational single-centre cohort study to evaluate the effectiveness of treating lupus nephritis with rituximab and mycophenolate mofetil but no oral steroids. Ann Rheum Dis. 2013;72(8):1280-1286. doi:10.1136/annrheumdis-2012-202844

22. Tedeschi B, Arnaud L, Hie M, Mathian A, Amoura Z. Successful treatment of combined proliferative and membranous lupus nephritis using a full corticosteroid-free regimen. Ann Rheum Dis. 2014;73(2):474-475. doi:10.1136/annrheumdis-2013-204385

23. Rovin BH, Solomons N, Pendergraft WF, et al. A randomized, controlled double-blind study comparing the efficacy and safety of dose-ranging voclosporin with placebo in achieving remission in patients with active lupus nephritis. Kidney Int. 2019;95 (1):219-231. doi:10.1016/j.kint.2018.08.025

24. Ruiz-Irastorza G, Danza A, Perales I, et al. Prednisone in lupus nephritis: how much is enough? Autoimmun Rev. 2014;13 (2):206-214. doi:10.1016/j.autrev.2013.10.013

25. Ruiz-Arruza I, Barbosa C, Ugarte A, Ruiz-Irastorza G. Comparison of high versus low-medium prednisone doses for the treatment of systemic lupus erythematosus patients with high activity at diagnosis. Autoimmun Rev. 2015;14 (10):875-879. doi:10.1016/j.autrev.2015.05.011

26. Fanouriakis A, Kostopoulou M, Alunno A, et al. 2019 update of the EULAR recommendations for the management of systemic lupus erythematosus. Ann Rheum Dis. 2019;78(6):736-745. doi:10.1136/annrheumdis-2019-215089

27. Gordon C, Amissah-Arthur MB, Gayed M, et al. The British Society for Rheumatology guideline for the management of systemic lupus erythematosus in adults: executive summary. Rheumatology (Oxford). 2018;57(1):14-18. doi:10.1093/rheumatology/kex291

28. Hahn BH, McMahon MA, Wilkinson A, et al. American College of Rheumatology guidelines for screening, treatment, and management of lupus nephritis. Arthritis Care Res (Hoboken). 2012;64(6):797-808. doi:10.1002/acr.21664

29. Pons-Estel BA, Bonfa E, Soriano ER, et al. First Latin American clinical practice guidelines for the treatment of systemic lupus erythematosus: Latin American Group for the Study of Lupus (GLADEL, Grupo Latino Americano de Estudio del Lupus)-PanAmerican League of Associations of Rheumatology (PANLAR). Ann Rheum Dis. 2018;77(11):1549-1557. doi:10.1136/annrheumdis-2018-213512 
30. Fanouriakis A, Kostopoulou M, Cheema K, et al. 2019 update of the Joint European League Against Rheumatism and European Renal Association-European Dialysis and Transplant Association (EULAR/ERA-EDTA) recommendations for the management of lupus nephritis. Ann Rheum Dis. 2020;79(6):713-723. doi:10.1136/annrheumdis-2020-216924

31. Lightstone L. Minimising steroids in lupus nephritis-will B cell depletion pave the way? Lupus. 2013;22(4):390-399. doi:10.1177/0961203313476155

32. Lightstone L, Doria A, Wilson H, Ward FL, Larosa M, Bargman JM. Can we manage lupus nephritis without chronic corticosteroids administration? Autoimmun Rev. 2018;17(1):4-10. doi:10.1016/j.autrev.2017.11.002

33. Tani C, Vagelli R, Stagnaro C, Carli L, Mosca M. Remission and low disease activity in systemic lupus erythematosus: an achievable goal even with fewer steroids? Real-life data from a monocentric cohort. Lupus Sci Med. 2018;5(1):e000234. doi:10.1136/lupus-2017-000234

34. Ruiz-Irastorza G, Ugarte A, Ruiz-Arruza I, Khamashta M. Seventy years after Hench's Nobel prize: revisiting the use of glucocorticoids in systemic lupus erythematosus. Lupus. 2020;29 (10):1155-1167. doi:10.1177/0961203320930099

35. Yang X, Sherwin CM, Yu T, Yellepeddi VK, Brunner HI, Vinks AA. Pharmacokinetic modeling of therapies for systemic lupus erythematosus. Expert Rev Clin Pharmacol. 2015;8 (5):587-603. doi:10.1586/17512433.2015.1059751

36. Struck RF, Alberts DS, Horne K, Phillips JG, Peng YM, Roe DJ. Plasma pharmacokinetics of cyclophosphamide and its cytotoxic metabolites after intravenous versus oral administration in a randomized, crossover trial. Cancer Res. 1987;47 (10):2723-2726.

37. Ntali S, Bertsias G, Boumpas DT. Cyclophosphamide and lupus nephritis: when, how, for how long? Clin Rev Allergy Immunol. 2011;40(3):181-191. doi:10.1007/s12016-009-8196-0

38. Mok CC, Ying KY, Ng WL, et al. Long-term outcome of diffuse proliferative lupus glomerulonephritis treated with cyclophosphamide. Am J Med. 2006;119(4):355 e325-333. doi:10.1016/j.amjmed.2005.08.045

39. de Groot K, Harper L, Jayne DR, et al. Pulse versus daily oral cyclophosphamide for induction of remission in antineutrophil cytoplasmic antibody-associated vasculitis: a randomized trial. Ann Intern Med. 2009;150(10):670-680. doi:10.7326/00034819-150-10-200905190-00004

40. Ioannidis JP, Katsifis GE, Tzioufas AG, Moutsopoulos HM. Predictors of sustained amenorrhea from pulsed intravenous cyclophosphamide in premenopausal women with systemic lupus erythematosus. J Rheumatol. 2002;29(10):2129-2135.

41. Mok CC, Wong RW, Lau CS. Ovarian failure and flares of systemic lupus erythematosus. Arthritis Rheum. 1999;42 (6):1274-1280. doi:10.1002/1529-0131(199906)42:6<1274::AIDANR26>3.0.CO;2-B

42. Takada K, Arefayene M, Desta Z, et al. Cytochrome P450 pharmacogenetics as a predictor of toxicity and clinical response to pulse cyclophosphamide in lupus nephritis. Arthritis Rheum. 2004;50(7):2202-2210. doi:10.1002/art.20338

43. Singh G, Saxena N, Aggarwal A, Misra R. Cytochrome P450 polymorphism as a predictor of ovarian toxicity to pulse cyclophosphamide in systemic lupus erythematosus. $J$ Rheumatol. 2007;34(4):731-733.

44. van Casteren NJ, van der Linden GH, Hakvoort-Cammel FG, Hahlen K, Dohle GR, van den Heuvel-eibrink MM. Effect of childhood cancer treatment on fertility markers in adult male long-term survivors. Pediatr Blood Cancer. 2009;52(1):108-112. doi: $10.1002 / p b c .21780$
45. Sabbour MS, Osman LM. Comparison of chlorambucil, azathioprine or cyclophosphamide combined with corticosteroids in the treatment of lupus nephritis. Br J Dermatol. 1979;100 (2):113-125. doi:10.1111/j.1365-2133.1979.tb05548.x

46. Austin HA, Klippel JH, Balow JE, et al. Therapy of lupus nephritis. Controlled trial of prednisone and cytotoxic drugs. $N$ Engl J Med. 1986;314(10):614-619. doi:10.1056/NEJM198603063141004

47. Houssiau FA, Vasconcelos C, D'Cruz D, et al. Immunosuppressive therapy in lupus nephritis: the Euro-Lupus Nephritis Trial, a randomized trial of low-dose versus high-dose intravenous cyclophosphamide. Arthritis Rheum. 2002;46 (8):2121-2131. doi:10.1002/art.10461

48. Houssiau FA, Vasconcelos C, D'Cruz D, et al. The 10-year follow-up data of the Euro-Lupus Nephritis Trial comparing low-dose and high-dose intravenous cyclophosphamide. Ann Rheum Dis. 2010;69(1):61-64. doi:10.1136/ard.2008.102533

49. Attia DHS, Eissa M, Samy LA, Khattab RA. Influence of glutathione $\mathrm{S}$ transferase A1 gene polymorphism $(-69 \mathrm{C}>\mathrm{T}$, rs3957356) on intravenous cyclophosphamide efficacy and side effects: a case-control study in Egyptian patients with lupus nephritis. Clin Rheumatol. 2021;40(2):753-762. doi:10.1007/ s10067-020-05276-0

50. Allison AC. Mechanisms of action of mycophenolate mofetil. Lupus. 2005;14(Suppl 1):s2-8. doi:10.1191/0961203305LU2109OA

51. Joy MS, Hilliard T, Hu Y, et al. Pharmacokinetics of mycophenolic acid in patients with lupus nephritis. Pharmacotherapy. 2009;29(1):7-16. doi:10.1592/phco.29.1.7

52. Mino Y, Naito T, Matsushita T, et al. Comparison of pharmacokinetics of mycophenolic acid and its glucuronide between patients with lupus nephritis and with kidney transplantation. Ther Drug Monit. 2008;30(6):656-661. doi:10.1097/ FTD.0b013e31818b8244

53. Dooley MA, Jayne D, Ginzler EM, et al. Mycophenolate versus azathioprine as maintenance therapy for lupus nephritis. $N$ Engl J Med. 2011;365(20):1886-1895. doi:10.1056/NEJMoa1014460

54. Appel GB, Contreras G, Dooley MA, et al. Mycophenolate mofetil versus cyclophosphamide for induction treatment of lupus nephritis. J Am Soc Nephrol. 2009;20(5):1103-1112. doi:10.1681/ASN.2008101028

55. Chan TM, Li FK, Tang CS, et al. Efficacy of mycophenolate mofetil in patients with diffuse proliferative lupus nephritis. Hong Kong-Guangzhou Nephrology Study Group. $N$ Engl J Med. 2000;343(16):1156-1162. doi:10.1056/NEJM200010193431604

56. Kapitsinou PP, Boletis JN, Skopouli FN, Boki KA, Moutsopoulos HM. Lupus nephritis: treatment with mycophenolate mofetil. Rheumatology (Oxford). 2004;43(3):377-380. doi:10.1093/rheumatology/keh012

57. Glicklich D, Acharya A. Mycophenolate mofetil therapy for lupus nephritis refractory to intravenous cyclophosphamide. Am J Kidney Dis. 1998;32(2):318-322. doi:10.1053/ajkd.1998.v32. pm9708620

58. Henderson LK, Masson P, Craig JC, et al. Induction and maintenance treatment of proliferative lupus nephritis: a meta-analysis of randomized controlled trials. Am J Kidney Dis. 2013;61 (1):74-87. doi:10.1053/j.ajkd.2012.08.041

59. Touma Z, Gladman DD, Urowitz MB, Beyene J, Uleryk EM, Shah PS. Mycophenolate mofetil for induction treatment of lupus nephritis: a systematic review and metaanalysis. $J$ Rheumatol. 2011;38(1):69-78. doi:10.3899/jrheum.100130

60. Mak A, Cheak AA, Tan JY, Su HC, Ho RC, Lau CS. Mycophenolate mofetil is as efficacious as, but safer than, cyclophosphamide in the treatment of proliferative lupus nephritis: a meta-analysis and meta-regression. Rheumatology (Oxford). 2009;48(8):944-952. doi:10.1093/rheumatology/kep120 
61. Zhu B, Chen N, Lin Y, et al. Mycophenolate mofetil in induction and maintenance therapy of severe lupus nephritis: a meta-analysis of randomized controlled trials. Nephrol Dial Transplant. 2007;22(7):1933-1942. doi:10.1093/ndt/gfm066

62. Rovin BH, Parikh SV, Hebert LA, et al. Lupus nephritis: induction therapy in severe lupus nephritis-should MMF be considered the drug of choice? Clin J Am Soc Nephrol. 2013;8(1):147-153. doi:10.2215/CJN.03290412

63. Walsh M, Solomons N, Lisk L, Jayne DR. Mycophenolate mofetil or intravenous cyclophosphamide for lupus nephritis with poor kidney function: a subgroup analysis of the Aspreva Lupus Management Study. Am J Kidney Dis. 2013;61(5):710-715. doi:10.1053/j.ajkd.2012.11.042

64. Radhakrishnan J, Moutzouris DA, Ginzler EM, Solomons N, Siempos II, Appel GB. Mycophenolate mofetil and intravenous cyclophosphamide are similar as induction therapy for class V lupus nephritis. Kidney Int. 2010;77(2):152-160. doi:10.1038/ ki.2009.412

65. Chan TM, Tse KC, Tang CS, Mok MY, Li FK. Hong Kong Nephrology Study G. Long-term study of mycophenolate mofetil as continuous induction and maintenance treatment for diffuse proliferative lupus nephritis. J Am Soc Nephrol. 2005;16 (4):1076-1084. doi:10.1681/ASN.2004080686

66. Laskari K, Mavragani CP, Tzioufas AG, Moutsopoulos HM. Mycophenolate mofetil as maintenance therapy for proliferative lupus nephritis: a long-term observational prospective study. Arthritis Res Ther. 2010;12(6):R208. doi:10.1186/ar3184

67. Fassbinder T, Saunders U, Mickholz E, et al. Differential effects of cyclophosphamide and mycophenolate mofetil on cellular and serological parameters in patients with systemic lupus erythematosus. Arthritis Res Ther. 2015;17:92. doi:10.1186/ s13075-015-0603-8

68. Mejia-Vilet JM, Arreola-Guerra JM, Cordova-Sanchez BM, Morales-Buenrostro LE, Uribe-Uribe NO, Correa-Rotter R. Comparison of lupus nephritis induction treatments in a Hispanic population: a single-center cohort analysis. J Rheumatol. 2015;42(11):2082-2091. doi:10.3899/ jrheum.150395

69. Dall'Era M, Solomons N, Federico R, Truman M. Comparison of standard of care treatment with a low steroid and mycophenolate mofetil regimen for lupus nephritis in the ALMS and AURA studies. Lupus. 2019;28(5):591-596. doi:10.1177/ 0961203319842924

70. Kittanamongkolchai W, Rukrung C, Supasiri T, et al. Therapeutic drug monitoring of mycophenolate mofetil for the treatment of severely active lupus nephritis. Lupus. 2013;22(7):727-732. doi:10.1177/0961203313486949

71. Luszczynska P, Pawinski T. Therapeutic drug monitoring of mycophenolic acid in lupus nephritis: a review of current literature. Ther Drug Monit. 2015;37(6):711-717. doi:10.1097/ FTD.0000000000000223

72. Yap DYH, Tam CH, Yung S, et al. Pharmacokinetics and pharmacogenomics of mycophenolic acid and its clinical correlations in maintenance immunosuppression for lupus nephritis. Nephrol Dial Transplant. 2020;35(5):810-818. doi:10.1093/ndt/gfy284

73. Luszczynska P, Pawinski T, Kunicki PK, Durlik M, AugustyniakBartosik H, Hurkacz M. Pharmacokinetics of free and total mycophenolic acid in adult lupus nephritis patients-implications for therapeutic drug monitoring. Eur J Clin Pharmacol. 2019;75 (3):371-379. doi:10.1007/s00228-018-2599-X

74. Alexander S, Fleming DH, Mathew BS, et al. Pharmacokinetics of concentration-controlled mycophenolate mofetil in proliferative lupus nephritis: an observational cohort study. Ther Drug Monit. 2014;36(4):423-432. doi:10.1097/FTD.0000000000000031
75. Pourafshar N, Karimi A, Wen $\mathrm{X}$, et al. The utility of trough mycophenolic acid levels for the management of lupus nephritis. Nephrol Dial Transplant. 2019;34(1):83-89. doi:10.1093/ndt/gfy026

76. Kiyokawa $\mathrm{T}$, Hanaoka $\mathrm{H}$, Iida $\mathrm{H}$, et al. High plasma mycophenolate acid concentration in the early phase of induction therapy predicts good renal outcome in lupus nephritis. Mod Rheumatol. 2020;30(3):517-524. doi:10.1080/14397595.2019.1623435

77. Sahasranaman S, Howard D, Roy S. Clinical pharmacology and pharmacogenetics of thiopurines. Eur J Clin Pharmacol. 2008;64 (8):753-767. doi:10.1007/s00228-008-0478-6

78. Kaballo BG, Ahmed AE, Nur MM, Khalid IO, Abu-Aisha H. Mycophenolate mofetil versus azathioprine for maintenance treatment of lupus nephritis. Saudi J Kidney Dis Transpl. 2016;27 (4):717-725. doi:10.4103/1319-2442.185233

79. Tamirou F, D'Cruz D, Sangle S, et al. Long-term follow-up of the MAINTAIN nephritis trial, comparing azathioprine and mycophenolate mofetil as maintenance therapy of lupus nephritis. Ann Rheum Dis. 2016;75(3):526-531. doi:10.1136/annrheumdis2014-206897

80. Weinshilboum R. Thiopurine pharmacogenetics: clinical and molecular studies of thiopurine methyltransferase. Drug Metab Dispos. 2001;29(4 Pt 2):601-605.

81. Coenen MJ, de Jong DJ, van Marrewijk CJ, et al. Identification of patients with variants in TPMT and dose reduction reduces hematologic events during thiopurine treatment of inflammatory bowel disease. Gastroenterology. 2015;149(4):907-917 e907. doi:10.1053/j.gastro.2015.06.002

82. Roy LM, Zur RM, Uleryk E, Carew C, Ito S, Ungar WJ. Thiopurine S-methyltransferase testing for averting drug toxicity in patients receiving thiopurines: a systematic review. Pharmacogenomics. 2016;17(6):633-656. doi:10.2217/pgs.16.12

83. Velo-Garcia A, Ntatsaki E, Isenberg D. The safety of pharmacological treatment options for lupus nephritis. Expert Opin Drug Saf. 2016;15(8):1041-1054. doi:10.1080/ 14740338.2016.1182496

84. McLeod HL, Siva C. The thiopurine S-methyltransferase gene locus implications for clinical pharmacogenomics. Pharmacogenomics. 2002;3(1):89-98. doi:10.1517/14622416.3.1.89

85. Gotestam Skorpen C, Hoeltzenbein M, Tincani A, et al. The EULAR points to consider for use of antirheumatic drugs before pregnancy, and during pregnancy and lactation. Ann Rheum Dis. 2016;75(5):795-810. doi:10.1136/annrheumdis2015-208840

86. Houssiau FA, D’Cruz D, Sangle S, et al. Azathioprine versus mycophenolate mofetil for long-term immunosuppression in lupus nephritis: results from the MAINTAIN nephritis trial. Ann Rheum Dis. 2010;69(12):2083-2089. doi:10.1136/ ard.2010.131995

87. Tian SY, Feldman BM, Beyene J, Brown PE, Uleryk EM, Silverman ED. Immunosuppressive therapies for the maintenance treatment of proliferative lupus nephritis: a systematic review and network metaanalysis. $J$ Rheumatol. 2015;42(8):1392-1400. doi:10.3899/jrheum.141650

88. Nee R, Rivera I, Little DJ, Yuan CM, Abbott KC. Cost-utility analysis of mycophenolate mofetil versus azathioprine based regimens for maintenance therapy of proliferative lupus nephritis. Int J Nephrol. 2015;2015:917567. doi:10.1155/2015/917567

89. Barbarino JM, Staatz CE, Venkataramanan R, Klein TE, Altman RB. PharmGKB summary: cyclosporine and tacrolimus pathways. Pharmacogenet Genomics. 2013;23(10):563-585. doi:10.1097/FPC.0b013e328364db84

90. Scalea JR, Levi ST, Ally W, Brayman KL. Tacrolimus for the prevention and treatment of rejection of solid organ transplants. Expert Rev Clin Immunol. 2016;12(3):333-342. doi:10.1586/ 1744666X.2016.1123093 
91. Ho S, Clipstone N, Timmermann L, et al. The mechanism of action of cyclosporin A and FK506. Clin Immunol Immunopathol. 1996;80(3 Pt 2):S40-45. doi:10.1006/clin.1996.0140

92. Kato A, Chustz RT, Ogasawara T, et al. Dexamethasone and FK506 inhibit expression of distinct subsets of chemokines in human mast cells. J Immunol. 2009;182(11):7233-7243. doi:10.4049/jimmunol.0801375

93. Moroni G, Ponticelli C. Synthetic pharmacotherapy for lupus nephritis. Expert Opin Pharmacother. 2017;18(2):175-186. doi:10.1080/14656566.2016.1276563

94. Hesselink DA, Bouamar R, Elens L, van Schaik RH, van Gelder T. The role of pharmacogenetics in the disposition of and response to tacrolimus in solid organ transplantation. Clin Pharmacokinet. 2014;53(2):123-139. doi:10.1007/s40262-013-0120-3

95. Zavada J, Sinikka Pesickova S, Rysava R, et al. Extended follow-up of the CYCLOFA-LUNE trial comparing two sequential induction and maintenance treatment regimens for proliferative lupus nephritis based either on cyclophosphamide or on cyclosporine A. Lupus. 2014;23(1):69-74. doi:10.1177/ 0961203313511555

96. Bao H, Liu ZH, Xie HL, Hu WX, Zhang HT, Li LS. Successful treatment of class $\mathrm{V}+\mathrm{IV}$ lupus nephritis with multitarget therapy. $J$ Am Soc Nephrol. 2008;19(10):2001-2010. doi:10.1681/ ASN.2007121272

97. Liu Z, Zhang H, Liu Z, et al. Multitarget therapy for induction treatment of lupus nephritis: a randomized trial. Ann Intern Med. 2015;162(1):18-26. doi:10.7326/M14-1030

98. Sakai R, Kurasawa T, Nishi E, et al. Efficacy and safety of multitarget therapy with cyclophosphamide and tacrolimus for lupus nephritis: a prospective, single-arm, single-centre, open label pilot study in Japan. Lupus. 2018;27(2):273-282. doi:10.1177/0961203317719148

99. Li X, Ren H, Zhang Q, et al. Mycophenolate mofetil or tacrolimus compared with intravenous cyclophosphamide in the induction treatment for active lupus nephritis. Nephrol Dial Transplant. 2012;27(4):1467-1472. doi:10.1093/ndt/gfr484

100. Yap DY, Yu X, Chen XM, et al. Pilot 24 month study to compare mycophenolate mofetil and tacrolimus in the treatment of membranous lupus nephritis with nephrotic syndrome. Nephrology (Carlton). 2012;17(4):352-357. doi:10.1111/j.1440-1797.2012.01574.x

101. Ikeuchi H, Hiromura K, Takahashi S, et al. Efficacy and safety of multi-target therapy using a combination of tacrolimus, mycophenolate mofetil and a steroid in patients with active lupus nephritis. Mod Rheumatol. 2014;24(4):618-625. doi:10.3109/14397595.2013.844397

102. Mok CC, Ying KY, Yim CW, et al. Tacrolimus versus mycophenolate mofetil for induction therapy of lupus nephritis: a randomised controlled trial and long-term follow-up. Ann Rheum Dis. 2016;75 (1):30-36. doi:10.1136/annrheumdis-2014-206456

103. Kamanamool N, Ingsathit A, Rattanasiri S, et al. Comparison of disease activity between tacrolimus and mycophenolate mofetil in lupus nephritis: a randomized controlled trial. Lupus. 2018;27 (4):647-656. doi:10.1177/0961203317739131

104. Zhang H, Liu Z, Zhou M, et al. Multitarget therapy for maintenance treatment of lupus nephritis. J Am Soc Nephrol. 2017;28 (12):3671-3678. doi:10.1681/ASN.2017030263

105. Cortes-Hernandez J, Torres-Salido MT, Medrano AS, Tarres MV, Ordi-Ros J. Long-term outcomes-mycophenolate mofetil treatment for lupus nephritis with addition of tacrolimus for resistant cases. Nephrol Dial Transplant. 2010;25(12):3939-3948. doi:10.1093/ndt/gfq322

106. Mok CC, To CH, Yu KL, Ho LY. Combined low-dose mycophenolate mofetil and tacrolimus for lupus nephritis with suboptimal response to standard therapy: a 12-month prospective study. Lupus. 2013;22(11):1135-1141. doi:10.1177/0961203313502864
107. Choi CB, Won S, Bae SC. Outcomes of multitarget therapy using mycophenolate mofetil and tacrolimus for refractory or relapsing lupus nephritis. Lupus. 2018;27:961203318758505.

108. Jesus D, Rodrigues M, da Silva JAP, Ines L. Multitarget therapy of mycophenolate mofetil and cyclosporine A for induction treatment of refractory lupus nephritis. Lupus. 2018;27:961203318758508.

109. Richaud-Patin Y, Soto-Vega E, Jakez-Ocampo J, Llorente L. P-glycoprotein in autoimmune diseases. Autoimmun Rev. 2004;3 (3):188-192. doi:10.1016/j.autrev.2003.08.002

110. Garcia-Carrasco M, Mendoza-Pinto C, Macias Diaz S, et al. P-glycoprotein in autoimmune rheumatic diseases. Autoimmun Rev. 2015;14(7):594-600. doi:10.1016/j. autrev.2015.02.006

111. Ragab SM, Soliman MA. P-glycoprotein-1 functional activity in $\mathrm{CD} 5+\mathrm{CD} 7+$ and $\mathrm{CD} 20+$ lymphocytes in systemic lupus erythematosus children: relation to disease activity, complications and steroid response. Egypt $J$ Immunol. 2013;20 (2):101-115.

112. Kansal A, Tripathi D, Rai MK, Agarwal V. Persistent expression and function of P-glycoprotein on peripheral blood lymphocytes identifies corticosteroid resistance in patients with systemic lupus erythematosus. Clin Rheumatol. 2016;35(2):341-349. doi:10.1007/s10067-015-3079-7

113. Picchianti-Diamanti A, Rosado MM, Scarsella M, Lagana B, D'Amelio R. P-glycoprotein and drug resistance in systemic autoimmune diseases. Int $J$ Mol Sci. 2014;15(3):4965-4976. doi:10.3390/ijms 15034965

114. Singh JA, Hossain A, Kotb A, et al. Treatments for lupus nephritis: a systematic review and network metaanalysis. $J$ Rheumatol. 2016;43(10):1801-1815. doi:10.3899/jrheum.160041

115. Lee YH, Song GG. Relative efficacy and safety of tacrolimus, mycophenolate mofetil, and cyclophosphamide as induction therapy for lupus nephritis: a Bayesian network meta-analysis of randomized controlled trials. Lupus. 2015;24(14):1520-1528. doi:10.1177/0961203315595131

116. Tian J, Luo Y, Wu H, Long H, Zhao M, Lu Q. Risk of adverse events from different drugs for SLE: a systematic review and network meta-analysis. Lupus Sci Med. 2018;5(1):e000253. doi:10.1136/lupus-2017-000253

117. Hannah J, Casian A, D’Cruz D. Tacrolimus use in lupus nephritis: a systematic review and meta-analysis. Autoimmun Rev. 2016;15 (1):93-101. doi:10.1016/j.autrev.2015.09.006

118. Kraaij T, Bredewold OW, Trompet S, et al. TAC-TIC use of tacrolimus-based regimens in lupus nephritis. Lupus Sci Med. 2016;3(1):e000169. doi:10.1136/lupus-2016-000169

119. Kuglstatter A, Mueller F, Kusznir E, et al. Structural basis for the cyclophilin A binding affinity and immunosuppressive potency of E-ISA247 (voclosporin). Acta Crystallogr D Biol Crystallogr. 2011;67(Pt 2):119-123. doi:10.1107/ S0907444910051905

120. Stalder M, Birsan T, Hubble RW, Paniagua RT, Morris RE. In vivo evaluation of the novel calcineurin inhibitor ISATX247 in non-human primates. J Heart Lung Transplant. 2003;22 (12):1343-1352. doi:10.1016/S1053-2498(03)00033-0

121. Furst DE. Pharmacokinetics of hydroxychloroquine and chloroquine during treatment of rheumatic diseases. Lupus. 1996;5 (Suppl 1):S11-15. doi:10.1177/0961203396005001041

122. Rainsford KD, Parke AL, Clifford-Rashotte M, Kean WF. Therapy and pharmacological properties of hydroxychloroquine and chloroquine in treatment of systemic lupus erythematosus, rheumatoid arthritis and related diseases. Inflammopharmacology. 2015;23(5):231-269. doi:10.1007/s10787-015-0239-y

123. Lee SJ, Silverman E, Bargman JM. The role of antimalarial agents in the treatment of SLE and lupus nephritis. Nat Rev Nephrol. 2011;7(12):718-729. doi:10.1038/nrneph.2011.150 
124. Wu SF, Chang CB, Hsu JM, et al. Hydroxychloroquine inhibits CD154 expression in CD4(+) T lymphocytes of systemic lupus erythematosus through NFAT, but not STAT5, signaling. Arthritis Res Ther. 2017;19(1):183. doi:10.1186/s13075-017-1393-y

125. Wallace DJ, Gudsoorkar VS, Weisman MH, Venuturupalli SR. New insights into mechanisms of therapeutic effects of antimalarial agents in SLE. Nat Rev Rheumatol. 2012;8(9):522-533. doi:10.1038/nrrheum.2012.106

126. An N, Chen Y, Wang C, et al. Chloroquine autophagic inhibition rebalances Th17/Treg-mediated immunity and ameliorates systemic lupus erythematosus. Cell Physiol Biochem. 2017;44 (1):412-422. doi:10.1159/000484955

127. Gao R, Wu W, Wen Y, Li X. Hydroxychloroquine alleviates persistent proteinuria in IgA nephropathy. Int Urol Nephrol. 2017;49(7):1233-1241. doi:10.1007/s11255-017-1574-2

128. Yang YZ, Liu LJ, Shi SF, et al. Effects of hydroxychloroquine on proteinuria in immunoglobulin A nephropathy. Am J Nephrol. 2018;47(3):145-152. doi:10.1159/000487330

129. Floris A, Piga M, Mangoni AA, Bortoluzzi A, Erre GL, Cauli A. Protective effects of hydroxychloroquine against accelerated atherosclerosis in systemic lupus erythematosus. Mediators Inflamm. 2018;2018:3424136. doi:10.1155/2018/3424136

130. Lopez P, Gomez J, Mozo L, Gutierrez C, Suarez A. Cytokine polymorphisms influence treatment outcomes in SLE patients treated with antimalarial drugs. Arthritis Res Ther. 2006;8(2): R42. doi:10.1186/ar1897

131. Lopez P, Gomez J, Prado C, Gutierrez C, Suarez A. Influence of functional interleukin 10/tumor necrosis factor-alpha polymorphisms on interferon-alpha, IL-10, and regulatory $\mathrm{T}$ cell population in patients with systemic lupus erythematosus receiving antimalarial treatment. $J$ Rheumatol. 2008;35(8):1559-1566.

132. Ponticelli C, Moroni G. Hydroxychloroquine in systemic lupus erythematosus (SLE). Expert Opin Drug Saf. 2017;16 (3):411-419. doi:10.1080/14740338.2017.1269168

133. Tsujimura S, Tanaka Y. Treatment strategy based on targeting P-glycoprotein on peripheral lymphocytes in patients with systemic autoimmune disease. Clin Exp Nephrol. 2012;16 (1):102-108. doi:10.1007/s10157-011-0520-3

134. Marmor MF, Kellner U, Lai TY, Melles RB, Mieler WF. Recommendations on screening for chloroquine and hydroxychloroquine retinopathy (2016 revision). Ophthalmology. 2016;123(6):1386-1394. doi:10.1016/j.ophtha.2016.01.058

135. Mahon GJ, Anderson HR, Gardiner TA, McFarlane S, Archer DB, Stitt AW. Chloroquine causes lysosomal dysfunction in neural retina and RPE: implications for retinopathy. Curr Eye Res. 2004;28(4):277-284. doi:10.1076/ ceyr.28.4.277.27835

136. Shulman S, Wollman J, Brikman S, Padova H, Elkayam O, Paran D. Implementation of recommendations for the screening of hydroxychloroquine retinopathy: poor adherence of rheumatologists and ophthalmologists. Lupus. 2017;26(3):277-281. doi:10.1177/0961203316660204

137. Putney JW. TRP, inositol 1,4,5-trisphosphate receptors, and capacitative calcium entry. Proc Natl Acad Sci U S A. 1999;96 (26):14669-14671. doi:10.1073/pnas.96.26.14669

138. Kuijpers TW, Bende RJ, Baars PA, et al. CD20 deficiency in humans results in impaired $\mathrm{T}$ cell-independent antibody responses. J Clin Invest. 2010;120(1):214-222. doi:10.1172/ JCI40231

139. Reff ME, Carner K, Chambers KS, et al. Depletion of B cells in vivo by a chimeric mouse human monoclonal antibody to CD20. Blood. 1994;83(2):435-445. doi:10.1182/blood. V83.2.435.435

140. Pescovitz MD. Rituximab, an anti-cd20 monoclonal antibody: history and mechanism of action. Am J Transplant. 2006;6(5 Pt 1):859-866. doi:10.1111/j.1600-6143.2006.01288.x
141. Montalvao F, Garcia Z, Celli S, et al. The mechanism of anti-CD20-mediated B cell depletion revealed by intravital imaging. J Clin Invest. 2013;123(12):5098-5103. doi:10.1172/ JCI70972

142. Vieira CA, Agarwal A, Book BK, et al. Rituximab for reduction of anti-HLA antibodies in patients awaiting renal transplantation: 1. Safety, pharmacodynamics, and pharmacokinetics. Transplantation. 2004;77(4):542-548. doi:10.1097/01. TP.0000112934.12622.2B

143. Kronbichler A, Windpessl M, Pieringer H, Jayne DRW. Rituximab for immunologic renal disease: what the nephrologist needs to know. Autoimmun Rev. 2017;16(6):633-643. doi:10.1016/j.autrev.2017.04.007

144. Rovin BH, Furie R, Latinis K, et al. Efficacy and safety of rituximab in patients with active proliferative lupus nephritis: the Lupus Nephritis Assessment with Rituximab study. Arthritis Rheum. 2012;64(4):1215-1226. doi:10.1002/art.34359

145. Weidenbusch M, Rommele C, Schrottle A, Anders HJ. Beyond the LUNAR trial. Efficacy of rituximab in refractory lupus nephritis. Nephrol Dial Transplant. 2013;28(1):106-111. doi:10.1093/ndt/gfs285

146. Salama AD, Pusey CD. Drug insight: rituximab in renal disease and transplantation. Nat Clin Pract Nephrol. 2006;2(4):221-230. doi:10.1038/ncpneph0133

147. Gomez Mendez LM, Cascino MD, Garg J, et al. Peripheral blood B cell depletion after rituximab and complete response in lupus nephritis. Clin J Am Soc Nephrol. 2018;13(10):1502-1509. doi: $10.2215 / \mathrm{CJN} .01070118$

148. Trivin C, Tran A, Moulin B, et al. Infectious complications of a rituximab-based immunosuppressive regimen in patients with glomerular disease. Clin Kidney J. 2017;10(4):461-469. doi:10.1093/ckj/sfw101

149. Gkrania-Klotsas E, Kumararatne DS. Serious infectious complications after rituximab therapy in patients with autoimmunity: is this the final word? Clin Infect Dis. 2021;72(5):738-742. doi:10.1093/cid/ciaa131

150. Md Yusof MY, Vital EM, Buch MH. B cell therapies, approved and emerging: a review of infectious risk and prevention during use. Curr Rheumatol Rep. 2015;17(10):65. doi:10.1007/s11926015-0539-7

151. Dyson JK, Jopson L, Ng S, et al. Improving testing for hepatitis B before treatment with rituximab. Eur J Gastroenterol Hepatol. 2016;28(10):1172-1178. doi:10.1097/MEG.0000000000000689

152. Clifford DB, Ances B, Costello C, et al. Rituximab-associated progressive multifocal leukoencephalopathy in rheumatoid arthritis. Arch Neurol. 2011;68(9):1156-1164. doi:10.1001/ archneurol.2011.103

153. Stabler S, Giovannelli J, Launay D, et al. Serious infectious events and immunoglobulin replacement therapy in patients with autoimmune disease receiving rituximab: a retrospective cohort study. Clin Infect Dis. 2021;72(5):727-737. doi:10.1093/cid/ ciaa127

154. Dominguez-Mozo MI, Toledano-Martinez E, RodriguezRodriguez L, Garcia-Montojo M, Alvarez-Lafuente R, Fernandez-Gutierrez B. JC virus reactivation in patients with autoimmune rheumatic diseases treated with rituximab. Scand J Rheumatol. 2016;45(6):507-511. doi:10.3109/ 03009742.2015.1135980

155. Nurmohamed MT. Newer biological agents in the treatment of rheumatoid arthritis: do the benefits outweigh the risks? Drugs. 2009;69(15):2035-2043. doi:10.2165/11318290-00000000000000

156. Sato M, Yamada M, Nakajima M, Miyama Y, Kitayama H. The case of Kawasaki disease after rituximab infusion triggered by human anti-chimeric antibodies. CEN Case Rep. 2020;9 (4):392-394. doi:10.1007/s13730-020-00492-8 
157. Tahir H, Rohrer J, Bhatia A, Wegener WA, Isenberg DA. Humanized anti-CD20 monoclonal antibody in the treatment of severe resistant systemic lupus erythematosus in a patient with antibodies against rituximab. Rheumatology (Oxford). 2005;44 (4):561-562. doi:10.1093/rheumatology/keh533

158. Furie R, Stohl W, Ginzler EM, et al. Biologic activity and safety of belimumab, a neutralizing anti-B-lymphocyte stimulator (BLyS) monoclonal antibody: a phase I trial in patients with systemic lupus erythematosus. Arthritis Res Ther. 2008;10(5): R109. doi:10.1186/ar2506

159. Chen Y, Yang M, Long D, et al. Abnormal expression of BAFF and its receptors in peripheral blood and skin lesions from systemic lupus erythematosus patients. Autoimmunity. 2020;53 (4):192-200. doi:10.1080/08916934.2020.1736049

160. Marcondes F, Scheinberg M. Belimumab in the treatment of systemic lupus erythematous: an evidence based review of its place in therapy. Autoimmun Rev. 2018;17(2):103-107. doi:10.1016/j.autrev.2017.11.013

161. Wallace DJ, Navarra S, Petri MA, et al. Safety profile of belimumab: pooled data from placebo-controlled Phase 2 and 3 studies in patients with systemic lupus erythematosus. Lupus. 2013;22 (2):144-154. doi:10.1177/0961203312469259

162. Hui-Yuen JS, Li XQ, Askanase AD. Belimumab in systemic lupus erythematosus: a perspective review. Ther Adv Musculoskelet Dis. 2015;7(4):115-121. doi:10.1177/1759720X15588514

163. Navarra SV, Guzman RM, Gallacher AE, et al. Efficacy and safety of belimumab in patients with active systemic lupus erythematosus: a randomised, placebo-controlled, phase 3 trial. Lancet. 2011;377(9767):721-731. doi:10.1016/S0140-6736(10)61354-2

164. Furie R, Petri M, Zamani O, et al. A Phase III, randomized, placebo-controlled study of belimumab, a monoclonal antibody that inhibits B lymphocyte stimulator, in patients with systemic lupus erythematosus. Arthritis Rheum. 2011;63(12):3918-3930. doi:10.1002/art.30613

165. Furie R, Rovin BH, Houssiau F, et al. Two-year, randomized, controlled trial of belimumab in lupus nephritis. $N$ Engl J Med. 2020;383(12):1117-1128. doi:10.1056/NEJMoa2001180

166. Atisha-Fregoso Y, Malkiel S, Harris KM, et al. Phase II randomized trial of rituximab plus cyclophosphamide followed by belimumab for the treatment of lupus nephritis. Arthritis Rheumatol. 2021;73(1):121-131. doi:10.1002/art.41466
167. Ward M, Tektonidou MG. Belimumab as add-on therapy in lupus nephritis. $N$ Engl J Med. 2020;383(12):1184-1185. doi:10.1056/ NEJMe2027516

168. Ginzler EM, Dooley MA, Aranow C, et al. Mycophenolate mofetil or intravenous cyclophosphamide for lupus nephritis. $N$ Engl $J$ Med. 2005;353(21):2219-2228. doi:10.1056/NEJMoa043731

169. Tsakonas E, Joseph L, Esdaile JM, et al. A long-term study of hydroxychloroquine withdrawal on exacerbations in systemic lupus erythematosus. The Canadian Hydroxychloroquine Study Group. Lupus. 1998;7(2):80-85. doi:10.1191/ 096120398678919778

170. Fessler BJ, Alarcon GS, McGwin G, et al. Systemic lupus erythematosus in three ethnic groups: XVI. Association of hydroxychloroquine use with reduced risk of damage accrual. Arthritis Rheum. 2005;52(5):1473-1480. doi:10.1002/art.21039

171. Ruiz-Irastorza G, Egurbide MV, Pijoan JI, et al. Effect of antimalarials on thrombosis and survival in patients with systemic lupus erythematosus. Lupus. 2006;15(9):577-583. doi:10.1177/ 0961203306071872

172. Siso A, Ramos-Casals M, Bove A, et al. Previous antimalarial therapy in patients diagnosed with lupus nephritis: influence on outcomes and survival. Lupus. 2008;17(4):281-288. doi:10.1177/ 0961203307086503

173. Pons-Estel GJ, Alarcon GS, McGwin G, et al. Protective effect of hydroxychloroquine on renal damage in patients with lupus nephritis: LXV, data from a multiethnic US cohort. Arthritis Rheum. 2009;61(6):830-839. doi:10.1002/art.24538

174. Shinjo SK, Bonfa E, Wojdyla D, et al. Antimalarial treatment may have a time-dependent effect on lupus survival: data from a multinational Latin American inception cohort. Arthritis Rheum. 2010;62(3):855-862. doi:10.1002/art.27300

175. Pons-Estel GJ, Alarcon GS, Hachuel L, et al. Anti-malarials exert a protective effect while Mestizo patients are at increased risk of developing SLE renal disease: data from a Latin-American cohort. Rheumatology (Oxford). 2012;51(7):1293-1298. doi:10.1093/rheumatology/ker514
The International Journal of Nephrology and Renovascular Disease is an international, peer-reviewed open-access journal focusing on the pathophysiology of the kidney and vascular supply. Epidemiology, screening, diagnosis, and treatment interventions are covered as well as basic science, biochemical and immunological studies. The manuscript management system is completely online and includes a very quick and fair peer-review system, which is all easy to use. Visit http://www.dovepress.com/testimonials.php to read real quotes from published authors. 